\title{
Vladimir Kolesarić
}

\section{POČECI EKSPERIMENTALNE PSIHOLOGIJE U HRVATSKOJ}

\author{
DOI 10.17234/9789531757782.1
}

Temelj suvremene znanstvene i primijenjene psihologije jest eksperimentalna psihologija, a za uvođenje i razvoj eksperimentalne psihologije u hrvatsko akademsko, znanstveno i intelektualno okružje, pa onda i u područje njezine primjene, zaslužne su i odgovorne tri ličnosti. Najvažniji je Ramiro Bujas, koji ima neprocjenjive i, zapravo, sudbinske zasluge za samu pojavu znanstvene psihologije u nas. Zatim, Elza Kučera, u nešto skromnijem opsegu, ali ipak vrlo značajnom. A za daljnji vrlo plodan razvitak, osobito poslije Drugoga svjetskog rata, neosporne zasluge ima Zoran Bujas. Zbog toga što je, dakle, nastanak i razvitak eksperimentalne psihologije u Hrvatskoj neodvojiv od ovih ličnosti i prikaz tog nastanka i razvitka nužno se veže uz njihov život i rad.

\section{Ramiro Bujas}

Ramiro Bujas utemeljitelj je psihologije u Hrvatskoj kao moderne, empirijske i neovisne znanosti. Prvi počeci vezani su uz Fiziološki institut na Medicinskom fakultetu u Zagrebu dvadesetih godina 20. stoljeća, u kojemu je profesor fiziologije František Smetanka Ramiru Bujasu, kao svom asistentu, omogućio da napravi (vjerojatno manje-više improvizirani) laboratorij za psihologiju. Kako opisuje Zoran Bujas, u tom se laboratoriju koristio inventar iz napuštene fizikalne zbirke bivšega plemenitaškog konvikta (Z. Bujas, 1973). Ramiro Bujas je aparate, pogotovo one iz područja optike, akustike i elektriciteta, popravljao, i, osim toga, od dijelova starih aparata konstruirao niz novih uređaja za miješanje boja, demonstriranje sukcesivnog i simultanog kontrasta, te za mjerenje vremena reakcije i osjetljivosti u različitim osjetnim područjima. To je bio prvi laboratorij

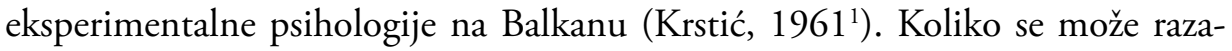
brati iz relativno šturih podataka u različitim člancima (Z. Bujas, 1973; Pavlina

Kruno Krstić u ovom članku, napisanom povodom smrti Ramira Bujasa, vrlo je lijepo i opširno prikazao djelovanje Ramira Bujasa. 
i Kovačić, 1973; Petz, 1979; Pavlina i Kolesarić, 1984; Pavlina i Kolesarić, 1987; Kolesarić i Pavlina, 1990; Pavlina i Kolesarić, 1991; Pavlina, Kolesarić, Matešić, and Topić, 2007), u tom su se laboratoriju izvodili demonstracijski pokusi za koje su bili zainteresirani studenti različitih studija Filozofskog fakulteta, pa vjerojatno i poneki student Medicinskog fakulteta.

Takav vrlo koristan običaj improviziranja i konstruiranja priručnog pribora i mjernih instrumenata za izvođenje psihologijskih laboratorijskih eksperimenata, kojemu je dao impuls Ramiro Bujas, postala je tradicija i kasnije osnovanog Psihologijskog instituta (Mayer, 1974) i taj je običaj trajao sve do pojave komercijalnih aparatura.

Glavni cilj Ramira Bujasa bio je otrgnuti psihologiju iz čvrstoga majčinskog zagrljaja filozofije, osobito teološki orijentirane filozofije, i utemeljiti je na empirijskim podacima dobivenim na prvom mjestu psihologijskim eksperimentom. Godine 1920. osnovao je psihologijsku katedru na Višoj pedagoškoj školi u Zagrebu, a godine 1929. Psihologijsku katedru, zajedno s Psihologijskim institutom, ${ }^{2}$ na Filozofskom fakultetu u Zagrebu. To je bio začetak znanstvene psihologije i nastave psihologije kao samostalne znanstvene, a vrlo brzo i primijenjene psihologije u Hrvatskoj (vidi prilog Katice Lacković-Grgin u ovoj knjizi).

Ramiro Bujas rođen je 1879. godine, godine u kojoj je Wilhelm Wundt osnovao prvi psihologijski laboratorij uopće. Ramiro Bujas otišao je na studij u Graz, a profesori iz Instituta za psihologiju Karl Franz sveučilišta u Grazu, H. P. Huber i I. Seybold (1999) u svom članku ukratko opisuju početke njegovog studija.

Ramiro Bujas upisao se 1899. godine na Filozofski fakuletet u Grazu. Tijekom akademske godine 1902./1903. prekinuo je taj studij i dva se semestra posvetio studiranju prava i političkih znanosti. Nakon izleta na Fakultetu pravnih znanosti, njegovi se interesi usmjeravaju prema filozofiji i slavenskoj filologiji. U području lingvistike najviše se zanimao za fiziologiju govora i psihologiju jezika. Godine 1903. Kraljevska akademija znanosti u St. Petersburgu povjerila mu je istraživanje različitih vrsta naglašenih slogova u čakavskom dijalektu u Dalmaciji, Istri i priobalnim područjima Hrvatske. Rezultat njegovog boravka u St. Petersburgu bile su dvije teze od kojih je jedna predložena kao doktorska disertacija (Huber i Seybold, 1999).

Naslov doktorske disertacije Ramira Bujasa bio je: Naglasci u čakavskim dijalektima Dalmacije, otocima Istre i u hrvatskom priobalju. Glavni ispitivač na doktorskom ispitu (tzv. rigorozu) bio je M. Murko, a drugi ispitivač K. Strekelj - oni su bili profesori u području lingvistike. Ispit iz filozofije, kao sporednog predmeta, održali su A. Meinong i E. Martinak. Tako je Ramiro Bujas 24. veljače 1906. godine proglašen doktorom znanosti (Huber \& Seybold, 1999).

2 Iz rukopisne ostavštine Zorana Bujasa. Nažalost, ta ostavština, nama dostupna, vrlo je skromna. Cjelokupna ostavština i Ramira i Zorana Bujasa nije nam dostupna. 
Zoran Bujas u članku o Ramiru Bujasu piše da je prvi susret Ramira Bujasa s psihologijom bio na Filozofskom fakultetu u Grazu za njegova studija slavistike, germanistike i filozofske propedeutike (Z. Bujas, 1973). Tamo je slušao predavanja iz psihologije kod profesora Meinonga, koji se u to vrijeme posebice bavio psihologijom mišljenja. Uz predavanja bio je organiziran i laboratorijski rad u psihologijskom institutu u Grazu koji je osnovao Meinong 1894. godine. Praktički rad sastojao se u samostalnim manjim istraživanjima i u sudjelovanju kao ispitanik pri pokusima koje su provodili Meinongovi suradnici - najpoznatiji među njima bili su Stephan Witasek (1870.-1915.) i Vitorio Benussi (1878.-1927.). Iz tog vremena potječe i prvi eksperimentalni rad Ramira Bujasa u području psihofiziologije govora, a sastojao se u konstrukciji i upotrebi posebnog aparata za bilježenje govornih akcenata.

Alexius Meinong (1853.-1920.), u svoje vrijeme značajno ime, bio je predvodnik Gradačke psihologijske škole. Bio je filozof-psiholog usmjeren na teorijsku psihologiju. Poznata je Meinongova "teorija predmeta“ (Gegenstandstheorie): prihvatio je Platonovu koncepciju idealnih objekata koji postoje kao i drugi postojeći predmeti, ali je dodao i treći aspekt - predmete koji ne postoje, ali imaju objektivna svojstva (Roeckelein, 2006). Marx i Cronan-Hallix (1987) navode da je Meinongova metodologija težila fenomenologiji pa se, na neki način, može smatrati jednim od preteča geštaltizma.

Meinong je studirao kod Franza Brentana (1838.-1917.), kad je on držao predavanja u Beču. Franz Brentano tvorac je tzv. psihologije akta, filozofsko-psihologijskog sustava, preteče funkcionalizma. Taj je sustav usmjeren na djelovanje (akte) i procese uma kao temeljne izvore empirijskih podataka (Roeckelein, 2006).

Godine 1874. Franz Brentano objavio je knjigu s naslovom Psychologie vom empirschen Standpunkte (Psihologija s empirijskog stajališta). To nije bila eksperimentalna psihologija, već traženje sustavne slike kako bi se dobila psihologija različita od mnogih tadašnjih.

U to je doba, 1874., Wundt objavio vjerojatno još značajniju knjigu koja je utjecala na promjene u položaju psihologije u okviru tadašnjih znanosti: Načela fiziološke psihologije. Obje ove knjige, kako kaže Boring (1950), predstavljaju pokušaj oblikovanja „nove“ psihologije kao zasebne znanosti. Među njima postoji, dakako, i razlika. Brentanova psihologija bila je empirijska, ali ne eksperimentalna, dok je Wundtova bila eksperimentalna. U predgovoru Wundt eksplicitno navodi da je to pokušaj prikaza novog područja znanosti (Benjamin, 2007). Brentano je organizirao svoj sustav oko fizičkog djelovanja (akta), a Wundt je izgradio svoj sustav na senzornom sadržaju. No jednako po važnosti, ako ne i važnije za sudbinu psihologije kao znanosti, bilo je to što je Wilhelm Wundt uveo psihologiju kao zasebni, samostalni predmet na univerzitetskoj razini. To je imalo svjetski utjecaj na razvitak znanstvene empirijske psihologije. U Wundtov laboratorij dolazili su znanstvenici iz svih krajeva zapadnog svijeta. Kod njega je doktoriralo 
više od 180 znanstvenika iz Europe i Sjedinjenih Američkih Država (Benjamin, Jr., 2007), a i mnogi filozofi (među njima i neki hrvatski) boravili su kod njega kraće ili duže vrijeme.

To je, dakle, bilo neposrednije intelektualno okružje Ramira Bujasa u koje je bio uronjen za studiranja u Grazu, a da je dobro je poznavao filozofiju-psihologiju Alexiusa Meinonga, pokazuje njegov dodatak Meinongovoj klasifikaciji tipova misli, tj. mislima odlučivanja i mislima fikcije (mašte), dodao je misli znanja temeljenih na predodžbama te misli vjerovanja koje ovise o emocijama (Krstić, 1961).

Huber i Seybold (1999) ovako opisuju pristup Ramira Bujasa u psihologiji (str. 13):

U terminima akta i sadržaja, Ramiro Bujas je bio predstavnik nove eksperimentalne psihologije sadržaja, na neki način, psihologije koja je akte smatrala neopipljivim fenomenima nepodložnim 'sustavnom eksperimentalnom opažanju'. Inzistiranje na pažljivim znanstvenim metodama, čak i kada je korištena metoda bila introspekcija, bilo je istaknuto obilježje Bujasovog pristupa psihologiji.

Ramira Bujasa na prvom mjestu spominjemo uvijek kad se radi o uvođenju eksperimentalne psihologije u krug hrvatskih znanosti, ali Ramiro Bujas se bavio i teorijskim i primijenjenim područjima. Tako Kruno Krstić (1961) piše o teorijskom stavu Ramira Bujasa (str. 6):

Prema njegovu mišljenju psihologija proučava psihičke fenomene i činjenice koji mogu biti izravno zahvaćeni introspekcijom i mogu biti znanstveno objašnjeni povezanošću s objektivnim uvjetima fizioloških promjena u organizmu i fizičkim promjenama u okolini.

Kruno Krstić (1961) najinteresantnijim radom Ramira Bujasa u teorijskom području smatra njegovu teoriju osjećanja. To je teorija koja odbacuje i teoriju pasiviteta, prema kojoj osjećanje nastaje isključivo zbog djelovanja okoline na organizam, i teoriju aktiviteta koja sugerira da je osjećanje autonoman čin koji nastaje u subjektu.

Eksperimentalni rad Ramira Bujasa nije velik, ali je važan za daljnji razvitak psihologije u Hrvatskoj. Možda je najviše Ramiro Bujas u to vrijeme, tj. dvadesetih godina 20. stoljeća, bio zaokupljen izučavanjem fizikalnih uvjeta tzv. psihogalvanskog fenomena, i to Tarhanovljeva tipa. $S$ radom o tom problemu habilitirao se Ramiro Bujas 1922. godine za privatnog docenta iz eksperimentalne psihologije na Filozofskom fakultetu u Zagrebu (Z. Bujas, 1973).

Godinu dana prije Ramiro Bujas objavio je članak u kojemu je ukratko opisao povijest „psihogalvanskog fenomena“, prijepore o značenju i dometima te pojave kao i rezultate svojih eksperimenta: 


\section{LIJEČNIČKI VJESNIK \\ ZNANSTVENI DIO}

God. 43. Zagreb, avgust 1921. Svezak 3.

Iz fiziološkog instituta kr. sveučilišta u Zagrebu; predstojnik prof. dr. Smetanka

\section{Istraživanja o fizičnim uvjetima psihogalvanskog fenomena}

Dr. phil. Ramiro Bujas, pristav, Zagreb

Budući da kod različitih autora postoji neslaganje i u pogledu fizičkog i fiziološkog porijekla psihogalvanskog fenomena, kao i u pogledu psihičnih prilika koje uvjetuju pojavu psihogalvanskog refleksa, Ramiro Bujas smatrao je nužnim najprije razjasniti tu pojavu ispitivanjem uvjeta bitnih za njezino pojavljivanje.

Postoje dvije vrste elektrodermalne reakcije (stariji izraz koji je rabio Ramiro Bujas bio je psihogalvanski fenomen). Jedna je Féréov efekt, tj. elektrodermalna reakcija kao rezultat smanjenja otpora (ili povećanja provodljivosti), koje ljudsko tijelo pruža vanjskom izvoru slabe električne struje. Otkriveno je da se otpor ljudskog tijela smanjuje prigodom različitih emocionalnih stanja.

Druga je tzv. Tarhanovljev efekt, odnosno elektrodermalna reakcija kao posljedica promjena slabih intenziteta struje što ih proizvodi sam organizam (Petz, 2005). Ramira Bujasa zanimao je ovaj drugi tip elektrodermalne reakcije, nazvan Tarhanovljev efekt: gruzijski fiziolog Ivane Tarkhanishvili, opazio je 1889. (radeći u Rusiji) promjene u kožnom električnom potencijalu i kad nije bilo nikakvog vanjskog podraživanja, pa je po njemu taj fenomen dobio naziv.

U spomenutom članku iz 1921. godine Ramiro Bujas detaljno i pre-

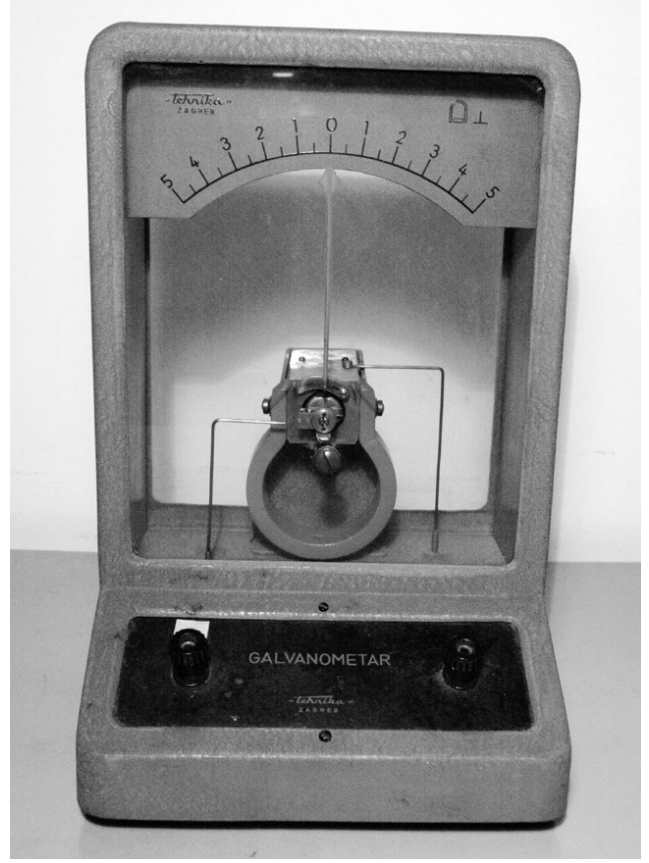

Slika 1. Galvanometar za mjerenje „psihogalvanskog efekta“ Feréeova tipa kakav se niz godina koristio za vježbe iz eksperimentalne psihologije u Odsjeku za psihologiju Filozofskog fakulteta u Zagrebu. Vjerojatno se i Ramiro

Bujas služio tim, ili takvim, galvanometrom pri istraživanjima elektrodermalne reakcije. ${ }^{3}$

3 Ovu fotografiju, još postojećeg galvanometra u Odsjeku za psihologiju, napravio je mag. sc. Robert Faber, inženjer elektrotehnike, suradnik u Odsjeku za psihologiju Filozofskog fakulteta u Zagrebu. Zahvaljujem mu na trudu. 
cizno opisuje fizičke uvjete nastanka psihogalvnaskog fenomena, a u završnom dijelu članka, između ostalog, zaključuje: „Kod psihogalvanskog fenomena mogu da sudjeluju i drugi fizični uvjeti, ali su odlučne samo termične prilike. Tumačenja, koja se oslanjaju na djelatnost znojnica ili na promjenljivi otpor tijela, imaju se smatrati zabludama“. Ramiro Bujas, nakon što je napravio velik broj eksperimenata, došao je do svog psihogalvanskog zakona prema kojemu je psihogalvanski fenomen objektivni indikator emocionalnih doživljaja: promjena potencijala registrirana na galvanometru pokazuje kvalitetu emocija, tj. ugodne ili neugodne osjećaje, sukladno smjeru kazaljke na galvanometru; stupanj pomaka kazaljke pokazuje intenzitet emocija, a razvoj u vremenu ukazuje na tijek emocionalnih promjena (Krstić, 1961).

Na slici 1 nalazi se fotografija galvanometra kakav je vjerojatno koristio Ramiro Bujas, na kojemu se kazaljka mogla pomicati na jednu ili drugu stranu skale.

Ramiro Bujas objavio je tri rada o svojim istraživanjima psihogalvanskog fenomena: Bujas, R., 1921 i 1922. U članku objavljenom 1937. godine, u jubilarnom, pedesetom broju časopisa The American Journal of Psychology, Ramiro Bujas piše o vezi između smjera toka struje i kvalitete emocija, koju je u svojim istraživanjima otkrio (slika 2).

Branko Sremec (1980) u članku „Psihogalvanski fenomen u istraživanjima Ramira Bujasa" spominje neke autore koji bi, iako ne izravno, potvrđivali zaključke Ramira Bujasa (prema Loveless \& Thetford, 1966).

Taj produbljeni interes Ramira Bujasa za psihogalvansku reakciju pokazuje njegovu stalnu, bazičnu usmjerenost objektivizaciji pokazatelja psihičkih pojava,

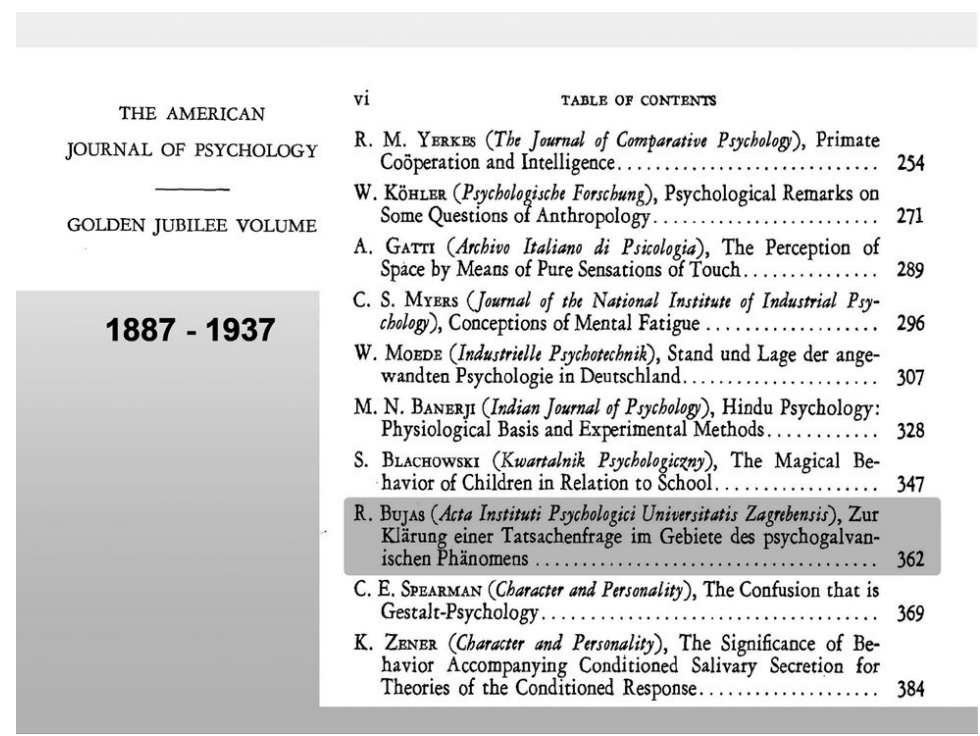

Slika 2. Dio sadržaja jubilarnog broja The American Journal of Psychology. 
u ovom slučaju emocija. U njegovo vrijeme, kad su u usporedbi s današnjom tehnologijom takva snimanja bila vrlo komplicirana - primjerice, elektrode su bile od bakra i trebalo ih je stalno brižljivo čistiti ako se željelo uspostaviti dobar kontakt s kožom opažanika, a galvanometri su bili najprimitivnije izrade - možemo retrogradno odati veliko priznanje takvim istraživačkim naporima. Osim toga radi se o izuzetno slabim strujama za pojačavanje kojih je potreban dobar uređaj, a u doba Ramira Bujasa bio je sasvim primitivan. Zbog tih i takvih razloga Ramiro Bujas nije mogao doći do vrlo valjanih rezultata u svojim istraživanjima.

Suvremeno snimanje elektrodermalne reakcije vrlo često se koristi kao zavisna varijabla u psihofiziološkim istraživanjima: u području uvjetovanja, psihopatologije, oblikovanja terapije, pokušaja detekcije varanja te socijalnoj psihologiji. Do opširnijih podataka i informacija može se doći u knjizi Prokasy, W.F \& Raskin, D. C. (Ed.) (1973) Electrodermal Activity in Psychological Research, New York, London: Academic Press, i u knjizi Boucsein, W. (2012), Electrodermal Activity, New York: Springer. ${ }^{4}$ Suvremena istraživanja ne potvrđuju pretpostavku Ramira Bujasa o različitom smjeru otklona koji bi uzrokovale ugodne ili neugodne emocije, a za obje vrste psihogalvanskog fenomena smatra se da je odgovoran simpatikus koji utječe na rad žlijezda znojnica.

\section{Dokimološka istraživanja}

„U plodnom životnom djelu Ramira Bujasa nalazimo i trajno vrijedan doprinos razvoju dokimoloških istraživanja u našim prilikama. Njegovo bogato nastavničko iskustvo i širok istraživački interes učinili su ga posebno osjetljivim za problematiku ispitivanja i procjenjivanja đačkih znanja u školama, pa svojim radovima iz tog područja krči putove razvoju naše dokimologije“" (Grgin, 1980, str. 29).

Tomislav Grgin (1986), ukratko prikazuje povijest nastojanja da se učenička postignuća u školi mjere što točnije i objektivnije. Pojavi dokimologije, kao posebne discipline, kojom su se na prvom mjestu bavili psiholozi, dala je poticaj Carnegieova fondacija 1931. godine povjerivši sveučilišnom institutu Columbia proučavanje, između ostalog, i načina ispitivanja i ocjenjivanja u školama. „Za realizaciju tog zadatka osnivaju se zasebni odbori u SAD, Velikoj Britaniji, Njemačkoj, Francuskoj i Švicarskoj, a sjedište generalnog tajništva organizacije smješta se u Pariz. U to vrijeme istaknuti francuski psiholog, Henri Piéron, iznosi ideju da područje ispitivanja i ocjenjivanja može biti predmetom nove psihologijske discipline kojoj daje naziv dokimologija" (Grgin, 1986, str. 6).

Henri Piéron (1896.-1964.), francuski psiholog, zaslužan za razvitak francuske znanstvene psihologije, biheivoristički orijentiran (Petz, 2005) - uveo je izraz doki-

\footnotetext{
Ove sam reference dobio ljubaznošću kolegice dr. sc. Ivane Hromatko, docentice u Odsjeku za psihologiju Filozofskog fakulteta u Zagrebu.
} 
mologija još 1922 . godine da bi opisao znanost o znanju i primjenu kontroliranja znanja. Inspirirana eksperimentalnom psihologijom, dokimologija se pojavljuje u novom pokretu usmjerenu obnovi obrazovanja na temelju znanstvenog pristupa. Iako je dokimologija zamišljena šire, najčešće se ipak bavi problemom ocjenjivanja u školskim i akademskim prilikama.

Dokimološka istraživanja u nas (kod T. Grgina, 1986, nalazi se iscrpan popis radova), koja je pokrenuo Ramiro Bujas (njegov prvi rad u području dokimologije, s naslovom „O ocjenjivanju“, objavljen je 1937. godine), na poticaj Henrija Piérona, i koja su sva empirijske naravi, provedena prema rigoroznim pravilima eksperimentalnog istraživanja, osim što nisu mogla biti provedena u laboratoriju (suvremenom terminologijom nazvali bismo ih kvazi-eksperimentalnim ili ne-eksperimentalnim istraživanjima jer su neka bila korelacijske naravi). Provedena su, dakle, in situ, što u znatnoj mjeri povećava njihovu vanjsku i ekološku valjanost.

Ta su istraživanja vrlo brižljivo i domišljato provođena. Primjerice, u jednom od njih školske zadaće koje su ocijenili nastavnici tako da su primjedbe i ocjene pisali na prozirnom papiru preko kojeg su čitali uratke, a zatim su iste zadaće dali nastavnicima iz druge škole, koji su ih ocjenjivali na jednak način, čitajući ih i stavljajući bilješke na prozirni papir (u ono vrijeme nije bilo „fotokopiranja“!). Tako su utvrdili da, na primjer, prvotno ocijenjene zadaće ocjenom „dobro“, pri ocjenjivanju drugih nastavnika mogu dobiti ocjene u čitavom rasponu od nedovoljnog do odličnog (Z. Bujas, 1941).

Nakon Ramira i Zorana Bujasa, Tomislav Grgin (1929.-2011.) je bio jedan od rijetkih istraživača u Hrvatskoj koji su se sustavno nastavili bavili dokimološkim pitanjima (Grgin, 1980, 1986, 1994, 1997, 2001, sa Z. Bujas, 1961). Nalazimo još samo imena Božice Bartolović (1986), Ivane Car-Gavrilović (1965), te Riste Đorđevskog (1964; makedonski profesor psihologije na studiju psihologije u Skopju, doktorirao kod Zorana Bujasa) koji su istraživali u tom području te još jedan rad: Bujas, R, Bujas, Z i Blašković, iz 1941.

Dokimološka istraživanja Ramira Bujasa, potom Zorana Bujasa, pa onda i drugih istraživača, potaknutih istraživačkom inicijativom Ramira Bujasa, pokazuju napor da se dobiveni rezultati stave na raspolaganje svima onima koji se dnevno susreću s procjenjivanjem i ocjenjivanjem učenika različitih razina. Korist od takvog upoznavanja leži na prvom mjestu u otkrivanju svih onih čimbenika koji umanjuju valjanost i pouzdanost školskog ocjenjivanja (Bartolović, 1991).

U članku „Provjeravanje znanja - ispitivač ili test? Zoran Bujas (1966) piše o objektivnosti ocjena, tj. ocjenjivanja znanja, pouzdanosti ocjena, osjetljivosti ocjena te točnosti (valjanosti) ocjena - dakle, o metrijskim karakteristikama procesa i rezultata ocjenjivanja znanja. Članak završava ovom rečenicom: „Prema tome odgovor na retoričko pitanje u naslovu ovog prikaza „'Ispitivač ili test?' glasi - i ispitivač i test". 
Malo je poznato da je Zoran Bujas klasificirao znanje u tri razine: deiktivnu, faktografsku te interpolativnu/ekstrapolativnu (prema sjećanju s predavanja $Z$. Bujasa). Testovima (ili kako se to danas zapravo redovito čini: nizom kojekako sastavljenih pitanja) mogu se manje-više dobro ispitati deiktivno (znati da nešto nije, npr. da Napoleon nije živio u 15. stoljeću) i faktografsko znanje (poput onoga na kvizovima), ali interpolativno i ekstrapolativno znanje testovima se teško ili nikako ne može ispitati na taj način, a jedino pravo znanje, znanje koje se može koristiti i u struci, ali i u svakidašnjem životu, jest upravo takvo znanje.

\section{Citljivost tiskanih slova, riječi i teksta}

Godine 1937. i 1938. Ramiro Bujas, u suradnji sa Zoranom Bujasom, objavio je nekoliko radova u kojima su prikazana eksperimentalna istraživanja čitljivosti tiskanog pisma (Bujas, R. und Bujas, Z., 1937a, 1937b, 1937c, 1938.). Godine 1937. Ivana Car obranila je diplomski rad Citljivost slova latinice $i$ ćirilice - ali nažalost, ta se radnja više ne nalazi u knjižnici Filozofskog fakulteta.

Nastavljajući istraživanja Ramira i Zorana Bujasa, Antun Rohaček je objavio dva rada: „Tahistoskopsko ispitivanje čitljivosti riječi pisanih ćirilicom i latinicom“ 1973. i „Čitljivost slova ćirilice i latinice u sklopu riječi i čestina njihova pojavljivanja" 1976., a 1978. godine obranio je magistarsku radnju s naslovom: Ispitivanje citljivosti latinice $i$ cirilice $i$ provjeravanje djelovanja gornjih $i$ donjih nastavaka slova na čitlivost riječi pisanih ćirilicom i latinicom.

Pojam „čitljivost“ odnosi se na fizički izgled tiskanog materijala: dužinu retka tiskanog teksta, veličinu slova, vrstu pisma (danas bi se reklo: font), razmak između redaka i između slova, margine, fizičku veličinu predloška, kontrast između slova i pozadine, boju slova i boju pozadine te faktore vidljivosti. To jest, čitljivost se odnosi na lakoću međusobnog razlikovanja slova za vrijeme čitanja. Kako se povećavala količina tiskanog materijala, postavljalo se opće pitanje brzine čitanja tiskanog materijala, tj. kako njegova fizička svojstva utječu na brzinu prepoznavanja i konzumiranja tiskanog teksta.

Potpuno je razumljiv interes Ramira i Zorana Bujas za pitanja čitljivosti jer su u to vrijeme, u Jugoslaviji, a dugo vremena i nakon Drugog svjetskog rata, latinica i ćirilica bili ravnopravna pisma, pa se postavljalo logično pitanje vezano uz vidnu percepciju i razumijevanje teksta: jesu li ta dva pisma jednako čitljiva ili postoji neka razlika među njima?

U jednom od prvih eksperimenata Ramiro i Zoran Bujas (1937a) koristili su jedan oblik tahistoskopske tehnike, tj. projicirali su izolirana slova latinice i ćirilice u kratkim ekspozicijama grupi sudionika. Glavni rezultat je da su izolirana latinska i ćirilična slova imala u prosjeku jednaku čitljivost.

U istraživanjima iz 1937. godine Ramiro i Zoran Bujas (1937b) ispitivali su čitljivost izoliranih slova latinice i ćirilice u indirektnom gledanju pomoću kam- 
pimetra. ${ }^{5}$ I ovdje su rezultati pokazali da su latinska i ćirilska slova u indirektnom mjerenju u prosjeku podjednako čitljiva.

U sljedećem istraživanju Ramiro i Zoran Bujas (1937c) koristili su kartonske predloške na kojima su slučajnim redom bila prilijepljena mala tiskana slova: na dva latinična, a na druga dva ćirilična, po osnovnim fizičkim karakteristikama jednaka. Zadaća sudionika bila je da pokazujući štapićem što brže imenuje svako slovo. Rezultati pokazuju da je čitanje latinice izrazito brže nego čitanje ćirilice.

Komentirajući rezultate prethodnih njihovih istraživanja, u kojima uglavnom nisu dobivali jasne razlike između čitljivosti latinice i ćirilice, Bujasi kažu ovo ${ }^{6}$ :

„Kod tahistoskopskih i kampimetrijskih ispitivanja uglavnom se radilo o prepoznavanju pojedinačnog ponuđenog slova na temelju nekog uočljivog fragmenta slova. Ni uvijek isto vrijeme ekspozicije, niti brzina percepcije nisu pri tome igrali odlučujuću ulogu. Suprotno tome nije se u prikazanom ispitivanju s kartonskim predlošcima sa slovima radilo samo o dopunjavanju uočenih dijelova slova, već o razlikovanju pojedinačnih slova među ostalim slovima istog pisma i o brzini kojom su u toj okolini mogla biti prepoznata. Budući da se kod stvarnog čitanja također ne radi o izoliranim slovima, postupak pomoću kartonskih predložaka sa slovima sličniji je stvarnosti od ostalih metoda za ispitivanje čitljivosti pojedinačnih pisanih znakova. Ne treba, dakako, prilikom vrednovanja ove osjetljive metode zaboraviti da se ovdje radi o prepoznavanju pojedinačnih slova u njima istovrsnoj okolini, što kod čitanja smislenih kompleksa sigurno igra važnu ulogu, pri čemu uvjeti čitljivosti tekstova pisanih različitim pismima time još nisu iscrpljeni“ (R. Bujas und Z. Bujas, 1937b).

Sudeći prema tom komentaru, autori ipak pretpostavljaju da se rezultati ovog eksperimenta mogu generalizirati na uobičajeno čitanje tiskanoga smislenog teksta, iako je čitanje smislenog materijala sasvim drugačiji proces, kakav nadilazi jednostavnu perceptivnu razinu. Vjerojatno svjesni te činjenice, u radu „Čitljivost latinice i ćirilice na osnovi najmanjeg osvjetljenja“ Ramiro i Zoran Bujas (1938) koristili su imena i tekst. Ustanovili su da je za čitanje latinice sudionicima trebalo u prosjeku 23\% manje svjetla nego za čitanje ćirilice.

Najveći problem pri ispitivanju čitljivosti latinice i ćirilice bila je uvježbanost sudionika u čitanju jednog i drugog pisma. Antun Rohaček (1973), u ispitivanju čitljivosti riječi pisanih latinicom i ćirilicom pri različitim tahistokopskim ekspozicijama, taj je problem riješio vrlo domišljato pomoću tzv. kontrolnih riječi. Nakon vrlo brižljivo provedenih eksperimenta sa studentima Filozofskog fakulteta, Antun Rohaček (1978) u svojoj magistarskoj radnji zaključuje: „1. Ispitivanjem čitljivosti rečenica pisanih ćirilicom, odnosno latinicom primjenom tahistoskopske tehnike, na grupi podjednako uvježbanih ispitanika u čitanju oba

5 Kampimetrija je mjerenje širine vidnog polja, a kampimetrom se mjeri širina vidnog polja.

6 Prevela prof. Mirjana Krizmanić 
pisma, dobiveno je da su rečenice pisane latinicom znatno čitljivije od rečenica pisanih ćirilicom. 2. Bolja čitljivost latinicom pisanih riječi, rečenica i teksta, koja se pokazala uglavnom u svim dosadašnjim ispitivanjima čitljivosti naših pisama, rezultat je i toga što slova latinice imaju veći broj gornjih ili donjih nastavaka, u odnosu na slova ćirilice, koji u sklopu riječi tvore karakterističnu razvedeniju strukturu i to kod većeg broja riječi nego što te razvedenije strukture možemo susresti kod ćirilicom napisanih riječi“".

No, danas istraživanja koje su provodili Bujasi i Rohaček o čitljivosti latinice i ćirilice nemaju značenje kakvo su mogla imati tada. Ona sada imaju više smisla promatramo li ih kao perceptivne eksperimente čiji rezultati mogu imati praktičnog značenja prilikom oblikovanja pisanog teksta i različitih poruka. I još važnija pouka: ti su eksperimenti provođeni vrlo brižljivo, a autori su stalno tražili nove načine kako bi došli do što valjanijih zaključaka.

\section{Modernizam i znanstvena psihologija u Hrvatskoj}

Ramiro Bujas nije napravio puno istraživanja i nije objavio puno radova. Njegov glavni, krucijalni doprinos je instaliranje znanstvene psihologije kao sveučilišnog studija u Hrvatskoj, a time i eksperimentalnih istraživanja u psihologiji, te nastojanja da javnim djelovanjem pokaže kako je psihologija ozbiljna disciplina, a ne mistična i metafizička spekulacija. U tim je nastojanjima nailazio na tvrd otpor.

Djelovanje Ramira Bujasa postaje jasnije i razumljivije ako se baci pogled u ono vrijeme i u tadašnje akademske prilike u Europi i u Hrvatskoj. Općenito, kraj 19. stoljeća i prva polovica 20. stoljeća karakterizirani su novim razvojem psihologije u zapadnom svijetu i povezani su s pojmom modernizma u znanosti. Modernizam označuje nov način mišljenja, veću otvorenost različitim utjecajima te često i radikalizam. U psihologiji modernizam se pojavljuje s prihvaćanjem eksperimentalnih metoda i simboličkim krajem filozofskih spekulacija. Formalno je počelo $s$ Wilhelmom Wundtom i njegovim strukturalizmom (Wundt nije koristio termin strukturalizam, već se smatrao voluntaristom); zatim, strukturalizmom Edwarda Titchenera (1867.-1927.); fiziologijom i psihologijom Ivana Petroviča Pavlova (1849.-1936.); poznatom knjigom Williama Jamesa (1842.-1910.) The Principles of Psychology objavljenom 1890.; pa zatim Johnom Watsonom (1878.1958.) i njegovim biheviorizmom; geštalt psihologijom koja se rodila pojavom članka Maxa Wertheimera (1880.-1943.) o prividnom gibanju (1912). Iako, za stvaran početak najzaslužniji su Gustav Theodor Fechner (1801.-1887.) i Ernst Heinrich Weber (1795.-1878.).

To su bila vremena u kojima se lomio tradicionalni, fenomenološki pristup i shvaćanje psihologije isključivo kao dijela filozofije te stvarao novi empirijski, eksperimentalni, kvantitativni pristup.

Stvaranje nove psihologije bilo je, zapravo, dijelom općeg napretka znanosti i tehnologije, naročito u području fizike i kemije. Wundt i dio njegovih sljedbenika 
tražili su elemente psihičkog života upravo po uzoru na kemiju i fiziku. Kako kaže Eduard Kale (1981) moderna znanost temelji se na eksperimentu, a jezik izražavanja je matematika. „Znanstvene spoznaje prethodnih razdoblja u osnovi su djelo pojedinaca, u ovom razdoblju znanost posve prelazi u velike laboratorije koji će postati presudna središta naše civilizacije i suvremenog svijeta."

Može se $s$ velikom sigurnošću ustvrditi kako je Ramiro Bujas dobro poznavao europska, pa i svjetska kretanja u psihologiji jer je aktivno sudjelovao na svjetskim kongresima eksperimentalne psihologije. Imao je 1922. godine predavanje s naslovom „Die physichen Bedingungen des psychogalvanischen Phänomens“ na VII. kongresu eksperimentalne psihologije u Marburgu. Godine 1926. sudjelovao je na IX. kongresu eksperimentalne psihologije u Münchenu s dva predavanje: „Über Kontreastempfindungen“ i „Zur Theorie des Empfindungsvorgangs“, a 1930. godine bio je na II Congrès Polonaise de Philosophie u Varšavi s predavanjem „Sur quelque principe de la théorie de la connaissance se base notre savoir des états de conscience d'autrui“".

Kakve su prilike u Hrvatskoj u to doba, koncem 19. i u prvoj polovici 20. stoljeća? B. Marotti (2016) daje sjajnu karakterizaciju:

„Taj pristup, u kojem se očituje određeni sklad, pa i uzajamna nadopuna znanosti i filozofije, nije se najčešće u Hrvatskoj u dvadesetome stoljeću uspijevao održati, čemu ima više razloga, tako da je između znanosti i filozofije, a posebice između prirodoslovlja i filozofije, uspostavljen stanovit jaz, gotovo raskol, za koji se katkada, sve do danas, čini nezacijeljiv. Tomu je nepovjerenju jamačno pridonijela i jedna i druga strana, ali kada je riječ o filozofiji, zanimljivo je da se u tome slažu i inače uzajamno posve suprotstavljeni pravci, kao što je recimo marksizam, posebice onaj 'stvaralački', s jedne strane, ali primjerice i fundamentalna ontologija, s druge. A takvo se shvaćanje odnosa znanosti i filozofije, naime uzajamnog nepovjerenja, dade uočiti i u Markovićeva ${ }^{7}$ učenika i ujedno nasljednika na katedri - Alberta Bazale.“

Hrvatski filozofi s kraja 19. i početka 20. stoljeća, među kojima se ističu Albert Bazala, Đuro Arnold, Stjepan Zimmermann, priklanjali su se, tada, tradicionalnim filozofskim strujama dobrim dijelom teološki utemeljenima.

Kako bi bile razumljivije bitke koje je vodio Ramiro Bujas, koje su katkada prelazile intelektualnu sferu (sa Stjepanom Zimmermannom se sudio), evo u najkraćim crtama prikaz filozofije nekoliko naših najznačajnijih filozofa toga doba ${ }^{8}$ koji su se intenzivno bavili psihologijom iz pozicija filozofije.

7 Franjo Marković (1845.-1914.). Od 1874. pa do kraja života profesor filozofije na Zagrebačkom sveučilištu (Grlić, 1982.).

8 Ovi su prikazi napravljeni prema podacima iz enciklopedija i rječnika i nikako nemaju pretenzija bilo kakve evaluacije. 
Albert Bazala (1877.-1947.) doktorirao je filozofiju 1900. na Filozofskom fakultetu u Zagrebu s temom: „Psihologijska nauka o apercepciji“.9 Godine 1905.-1906. nastavio je studij filozofije u Münchenu, Jeni, Halleu te Leipzigu kod Wilhelma Wundta, koji je, kako kažu, utjecao na njegovo formiranje kao mislioca. Kao profesor Filozofskog fakulteta u Zagrebu (od 1909.) predavao je sve discipline teorijske i praktične filozofije, povijest filozofije te sociologiju i psihologiju. Za Bazalu, kao filozofskog mislioca karakterističan je „voluntaristički aktivizam" ${ }^{10}$ (Hrvatska opća enciklopedija, 1999).

Đuro Arnold (1853.-1941.) osnovao je pedagoški seminar na Filozofskom fakultetu u Zagrebu. Negira psihologiju kao induktivnu znanost jer ona proučava samo pojave svijesti, a ne dušu. Egzistenciju duše nužno je prihvatiti kao supstancijalni entitet. Psihologija mora ostati dio metafizike, eksperimentalna istraživanja ne mogu se zvati psihologijom, nego "psihofizikom“. Od 1984. do 1923. na Sveučilištu u Zagrebu predaje psihologiju, psihologiju spoznaje, psihologiju čuvstava i volje, uvod u filozofiju, osnovne probleme metafizike i dr. (Hrvatska opća enciklopedija, 1999). Napisao je Psihologiju za srednja učilišta 1893. godine, koja je doživjela najmanje sedam izdanja (knjižnica Filozofskog fakulteta u Zagrebu ima izdanje iz 1923. godine).

Stjepan Zimmermann (1884.-1936.) bio je katolički svećenik, profesor filozofije na Teološkom fakultetu u Zagrebu. „U mnogobrojnim djelima s područja spoznajne teorije, ontologije i psihologije zastupao je, u okviru svoje neoskolastički ${ }^{11}$ orijentirane filozofije, specifični intelektualizam i objektivizam" (Grlić, 1982). Objavio je 1923. godine knjigu Temelji psihologije s podnaslovom „Opća nauka o svjesnom životu ljudske duše“. Stjepan Zimmerman bio je jedan od istaknutijih predstavnika hrvatske neoskolastike (Šestak, 2010).

Još nešto bolji uvid u kulturne i svjetonazorske prilike u vrijeme kada je Ramiro Bujas uvodio znanstvenu psihologiju na zagrebačko Sveučilište, daje pogled u knjige Đure Arnolda i Stjepana Zimmermanna, koje su u temeljnim pristupima slične. Đuro Arnold govori o nižim i višim duševnim tvorevinama. Stjepan Zimmermann govori o empiričkoj i racionalnoj psihologiji. Niža i empirička psihologija odnosi

\footnotetext{
Apercepcija. 1. Čin ili proces svjesnog percipiranja; 2. Mentalni proces kojim je percepcija ili ideja asimilirana u nečije već postojeće znanje, misli i emocije (VandenBos, G. R, 2007). Proces uključivanja percepcije njezinim integriranjem sa sličnim ili povezanim percepcijama ili prethodno stečenim znanjem; također, svijest o činu ili doživljaju percipiranja. (Colman, 2006).

10 Prema Filozofijskom rječniku (Filipović, 1965) „psihološkim voluntarizmom naziva se teorija po kojoj je volja osnovna funkcija duševnog života i iz nje proizlazi i mišljenje i čuvstvovanje“ „Voluntarističku tezu o teorijama nauka zastupaju pozitivisti, pragmatisti i konvencionalisti koji smatraju da je svagda osnovna voljna postavka odlučna za cjelinu naučne koncepcije i izučavanja, a razum je samo oruđe volje. Suprotno: intelektualizam.“

11 Skolastika. Sustavna filozofsko-teološka spekulacija koja je sadržajno željela dovesti u harmonijsko jedinstvo spasenjsko značenje kršćanske objave s filozofskim mišljenjem. U vrijeme Renesanse uglavnom je zamrla. Neoskolastika je oživljavanje skolastike sredinom 19. stoljeća (Šestak, 2010).
} 
se na „novu psihologiju“, kako često tada nazivaju psihologijska dostignuća koja su izvirala iz sve bujnijeg razvitka eksperimentalne psihologije. Ova dva autora, kao i mnogi drugi toga doba, „nižu“ ili „empiričku“ psihologiju smatraju samo nekim nužnim osnovama koje karakteriziraju ljudsko biće, ali nikako pravom psihologijom. Zapravo, filozofi toga doba, i u Europi kao i u Hrvatskoj bore se sa - da se malo našalimo - svojevrsnim „separacijskim sindromom“: ne mogu prihvatiti da i psihologija odlazi iz krila „majčice filozofije“.

Iako su hrvatski filozofi, čini se, dosta dobro poznavali Wundtov rad, i, čak, relativno ga korektno prikazivali u okviru svoje „niže“ ili „empiričke“ psihologije, ipak su ostajali na svojim metafizičkim, skolastičkim ili sličnim pozicijama. Djelomično, čini mi se, tome je pridonio i sam Wundt. Wundtov cilj bio je razumjeti svijest (svjesnost), a slijeđenje tog cilja bilo je u tradiciji njemačkog racionalizma. Njegov je cilj bio ne samo razumjeti svijest (svjesnost) kako se ona doživljava nego, također, razumjeti mentalne zakone koji pokrivaju dinamiku svijesti. Najveću važnost za Wundta imao je koncept volje kako se on odražava u pažnji i snazi volje. Wundt je smatrao da je volja središnji koncept u okviru kojega se svi glavni problemi u psihologiji moraju razumjeti. Vjerovao je da ljudi mogu odlučiti na što će usmjeriti svoju pažnju i tako odlučiti što će jasno percipirati; većina ponašanja i selektivne pažnje je na neki način motivirano. Ime koje je Wundt dao svom pristupu u psihologiji je voluntarizam, jer se temelji na volji ${ }^{12}$, izboru i svrsi (Hergenhahn, 2001).

Godine 1938. poznati profesor filozofije zagrebačkog Sveučilišta, Vladimir Filipović (1906.-1984.) objavio je knjigu s naslovom Moderna psihologija u pedagogiji. Tekst je zanimljiv i, naizgled, pomirljiv u smislu prihvaćanja suvremene psihologije, ali jedan pasus (str. 44) glasi: „Pa kao što je prirodoznanstvena psihologija tumačila subjektivne doživljaje dovodeći ih u vezu s objektivnim, materijalnim svijetom, tako duhoznanstvena psihologija nastoji razumjeti subjektivne doživljaje u vezi s objektivnim duhom".

Nekoliko godina kasnije, 1943., Ramiro Bujas objavio je poduži članak u Napretku naslovljen „Pitanje duhoznanstvene psihologije“. U završnim pasusima članka Ramiro Bujas kaže ovako:

„Ne postoje dvije psihologije - prirodoznanstvena psihologija i duhoznanstvena psihologija - nego postoji samo jedna, a to je psihologija psihologa. (...) Ta koncepcija (duhoznanstvene psihologije, op. V. K.) nije izpunila što se od nje

12 Volja. „1. U filozofiji duhovni čin koji omogućava da ono što je svjesno spoznato( neki predmet, neka vrjednota, nešto što se namjerava itd.) istodobno doživi kao svoje praktično ozbiljenje. Dok je spoznaja u svojem izvršenju ovisna o tome što ona spoznaje, što određuje pristup i način njezina spoznavanja, volja je u metafizičkom smislu potpouno slobodna, i to dvostruko: ona nije uvjetovana nikakvikm predmetom ni bilo kakvom spoznajom, ali samoj toj spoznaji tek omogućuje da se prema tomu predmetu odnosi ne samo teorijski nego i djelatno. Sloboda voelje izvire stoga iz njezine potpune oslobođenosti kauzalnog niza uzrokâ i posljedicâ. (...)“ (Hrvatska enciklopedija, el. izdanje). „1. U staroj psihologiji moći jedna od triju osnovnih psihičkih moći čovjeka (druge dvije su intelekt i čuvstva ili emocije)“ (Petz, 2005). 
očekivalo. Nije se postiglo ni ono, što je htio Dilthey ${ }^{13}$, t. j. da bi se duhoznanstvenom metodom mogla sa sigurnošću rekonstruirati duševna obilježja poviestnih ličnosti, pa se nije postiglo ni to, da 'psihologija, koja razumije' posluži uobće kao posebna znanstvena disciplina za upoznavanje pojedinih subjekata te tako dopuni istraživački rad 'psihologije, koja tumači', kako je želio Spranger. ${ }^{14}$ Nije se dakako izpunila ni ničim opravdana nada nekih psihologijskih lajika, da bi duhoznanstvena psihologija zamienila stručnu psihologiju."

U knjižici (od 52 stranice) Kretschmerov konstitucionalizam tiskana je godine 1941. disertacija Margite Čeh. Ispod naslova stoji: „Radnja odobrena kao disertacija za doktorski ispit na VII. redovitoj sjednici Vijeća Filozofskog fakulteta, Sveučilišta Nezavisne Države Hrvatske od 30. srpnja 1941. prema referatu članova ispitnog odbora: gg. dr. Ramira Bujasa i dr. Vlade Petza. ${ }^{15} \mathrm{U}$ završnoj rečenici Margita Čeh zaključuje da Kretschmerova karakterologija, osnovana na konstitucionalizmu i endokrinologiji, nije naučni prinos znanstvenim karakterologijskim istraživanjima sa stajališta naučne empirijske psihologije.

Napokon, 1945. godine objavljena je knjiga Zorana Bujasa Elementi psihologije, moderni na znanosti temeljen udžbenik za srednje škole.

Iako se tzv. duhoznanstvenom psihologijom bave još, možda, samo neki filozofi, ipak u Hrvatskoj općoj enciklopediji iz 2001. stoji ovako: „duhoznanstvena psihologija, smjer u psihologiji gdje je jedino spoznajno sredstvo individualna duhovna struktura; služi se metodom objašnjavanja i metodom razumijevanja. U modernoj psihologiji ubraja se u tzv. introspekcionističke smjerove psihologije; pripisuje se njem. filozofu E. Sprangeru i njegovu učitelju W. Diltheyu“.

Neće biti nezanimljivo spomenuti što Franjo Zenko (1995) navodi pišući o Đuri Arnoldu. Godine 1899. Đuro Arnold, prilikom „ustoličenja“ za rektora zagrebačkog Sveučilišta održao je javni govor s naslovom „Filozofija, prirodne nauke i sociologija, i podnaslovom „Riječ u prilog metafizici“. U njemu se Đuro Arnold suprotstavlja određenim antimetafizičkim tendencijama što se javljaju jačim zamahom prirodnih znanosti u sklopu Hrvatskog sveučilišta i Akademije. Dalje Franjo Zenko (1995) spominje i filozofske reakcije na „duh pozitivizma što prodire novim idejama u sociologiji, u prirodoslovlju i fizikalistički usmjerenoj psihologiji“.

Koliko je poznato, prvu knjigu iz psihologije objavio je Stjepan Basariček (1848.1919.) 1877. godine. Bio je profesor teorijske i praktične pedagogije (metodike)

13 Dilthey, Wilhelm (1833.-1911.), njemački filozof, „Na području psihologije D. se također suprotstavlja naturalističkom smjeru, koji bi htio postaviti kauzalne slijedove, i traži novo duhoznanstveno usmjeravanje psihologije. Pri tom je naročito karakterisično naglašavanje karaktera, cjelovitosti svih psihičkih funkcija, doživljaja, operacija i sl.“ (Grlić, 1982).

14 Spranger, Eduard (1882.-1963.), njemački filozof, „U svom glavnom djelu „oblici života“ kritizira prirodoznanstvene orijentacije psihologije koje ne mogu doprijeti do ljudske duševnosti i koje ubijaju njenu živu dinamiku, svodeći čovjeka na njegovu nagonsku i osjetilnu prirodu i negirajući - svojim raščlanjivanjem i seciranjem - cjelinu, totalitet duševnog života" (Grlić, 1982).

15 Vlado Petz, profesor pedagogije, bio je otac dobro poznatog profesora u Odsjeku za psihologiju Filozofskog fakulteta u Zagrebu Borisa Petza. 
na učiteljskoj školi u Zagrebu. U ruci imam „drugo znatno preradjeno izdanje“ iz 1878. godine. Knjiga ima 96 stranica manjeg formata. Ganutljiva je naivnost kojom odiše ovaj tekst. Evo jednog kraćeg citata: „Mi opažamo na sebi razne pojave, koji nikako ne pripadaju našem tielu, tako npr. mislimo, čustvujemo i hoćemo; odtud zaključujemo, da mora biti u nas osim tiela još neko biće, komu ti pojavi pripadaju, t. j. koje misli, čustvuje i hoće. - To biće zovemo dušom" (str. 11).

No, nešto stariji je tekst Josipa Glasera, koji je u nekoliko nastavaka izlazio u časopisu Napredak, časopisu „za učitelje, odgojitelje i sve prijatelje mladeži“ kao glasilo „Hrvatskoga pedagogijsko-književnoga sbora“. Tekst s na slovom „Oris psihologije“ počeo je izlaziti 1. studenog 1875. (Tečaj XVI. Br. 31). Josip Glaser tuži se kako se u nas o psihologiji ništa ne piše. On je bio pedagog, između ostalog predavao je na „preparandiji“ u Petrinji psihologiju. Tekst se može čitati sa zanimanjem, između ostalog i zato što je pisan, za nas danas, arhaičnim jezikom, ali jezikom u kojemu se nastoji svim mogućim terminima dati hrvatski naziv. Počinje s opisom osjetila i na početku navodi kako se „svako osjećalo sastoji od triju česti: a) perifernog diela, b) srednjeg diela tj. živaca, koji posreduju medju spravami i mozgom, i c) centralnog dijela tj. mozga, glavnog orudja našeg duševnog rada“. U Hrvatskoj enciklopediji (1999) stoji da je Josip Glaser bio zastupnik empirijske psihologije u pedagogiji. To je i razlogom da ga ovdje spominjem jer, doista, ako se uzme u obzir doba kad je pisan, može se vidjeti da je puno manje kontaminiran neznanstvenim natruhama, za razliku od nekih kasnijih tekstova o psihologiji kod nas. ${ }^{16}$

Srećom, i u Hrvatskoj u to su vrijeme prodirala znanstvena stajališta, barem u područjima medicine i veterine. Medicinski fakultet u Zagrebu osnovan je 1917. godine, a Veterinarski fakultet dvije godine kasnije. Nastava iz prirodoslovlja i matematike postoji na Mudroslovnom fakultetu već od 1876. godine.

Ipak, ne bi bilo opravdano ne spomenuti da su ti srednjoškolski udžbenici iz psihologije, koje su pisali tadašnji hrvatski filozofi i pedagozi (u 19. i početkom 20. stoljeća), možda na neki način olakšali, namjerno ili nenamjerno, put znanstvenoj psihologiji, opisujući područja i znanstvene činjenice osjetne psihologije, percepcije, pažnje, pamćenja i sl.

\section{Ostavština Ramira Bujasa}

Uvodeći eksperimentalnu psihologiju u hrvatski znanstveni sustav, Ramiro Bujas se opredijelio za kvantitativni pristup, koji je, uostalom, sastavni dio eksperimenta, a to se opredjeljenje dobro vidi u sadržaju knjige Dobivanje psihologijskih podataka i njihovo računsko obradivanje koju su 1942. objavili Ramiro i Zoran Bujas. Ta je knjiga, ustvari, prava psihometrija, a to se može iščitati već i iz sadržaja knjige. Na početku knjige nalazi se ukratko opisana metodologija psihologije, zapravo eksperimentalne psihologije, uključujući i probleme mjerenja

16 Tekst mi je pribavila, uvijek spremna na pomoć, kolegica Marijana Glavica uz određene komplikacije jer se nalazi u više brojeva časopisa Napredak i zato joj još posebice zahvaljujem. 
u psihologiji. Središnji dio knjige sadrži temelje statistike kako se ona koristi u psihologijskim istraživanjima, pa potom i psihometrija u užem smislu: govori se o testu kao jednom od najvažnijih psihologijskih mjernih instrumenata. Taj tekst, uz dužno respektiranje vremenskog pomaka, i danas se može koristiti (slika 3).

S A D R Ž A I :

Predgovor

I. DOBIVANJE PSIHOLOGIJSKIH PODATAKA

1. Metodika psihologije uopće

a) Samoopažanje ili introspekcija

2. Pomagala psihologijskog istraživanja

a) Eksperimenat u psihologiji

b) Laboratorij

3. Mjerenje u psihologiji

II. RAĆUNSKO OBRAĐIVANJE PODATAKA

1. Reprezentativne vrijednosti

a) Centralna vrijednost ili medijan (C)

b) Dominantna vrijednost ili mod (D)

c) Aritmetična sredina $(S)$

2. Indeksi promjenljivosti

a) Srednja pogrješka ( $\left.P_{s}\right)$.

b) Vjerojatna pogrješka ( $P$,

c) Srednja kvadratna pogrješka ili standardna pogrješka $(\dot{\sigma})$

d) Koeficijenat relativne promjenljivosti $(V)$

3. Grafično prikazivanje rezultata

a) Krivulja čestine (Gaussova krivulja)

b) Krivulja ranga (Galtonova oživa)

c) Normalna krivulja čestine

4. Upotreba normalne krivulje

a) Broi rezultata $u$ nekom intervalu i vjerojatnost pojedinih rezutata

b) Određivanje brojčane vrijednosti za neki postotak slučajeva

c) Srednja vrijednost dijela normalne krivulje . : 56

5. Preciznost reprezentativnih vrijednosti

a) Indeks preciznosti aritmetične sredine

b) Indeks preciznosti centralne vrijednosti

c) Indeks preciznosti nekog odnosa rezultata

6. Upotreba indeksa preciznosti reprezentativnih vrijednosti

a) Korigirana srednja vrijednost

b) Preciznost razlike izmedu dvije srednie vrijednost

c) Preciznost razlike izmedu dva indeksa dispersije

7. Korelacija

a) Pe arsono v koeficijenat korelacije $r$

b) Spearmanov koeficijenat korelacije

c) Yul e-ov koeficijenat asocijacije

d) Pearsonov koeficijenat kontingencije $K$

e) Indeksi pogrieške koeficijenata korelaci.je

f) Graficno prikazivanje korelacije

g) Značenje korelacije

III. PSIHOLOGIJSKI TEST

1. Opća svojstva testa

a) Simptomatična vrijednost testa

b) Endogeni i eksogeni uvjeti reakcije

c) Razdioba testova

d) Telnnika testiranja

2. Baždarenje testa

a) Baždarenje testa prema postotku ispravnih rješenja

b) Baždarenje u odnosu prema reprezentativnoj vrijednost

c) Baždarenje prema ordinati moda

d) Metoda décila ili centila

e) Metoda smanjenih razlika

f) Tetroniranje

g) Baždarenje baterije testova

3. Metrijske karakteristike testa

a) Vjernost testa

c) Objektivnost test

d) Osjetljivost testa

LITERATURA 
Ramiro Bujas ostavio je relativno skromnu pisanu ostavštinu. Njegovo djelovanje bilo je, $s$ jedne strane, usmjereno na institucionaliziranje psihologije kao zasebne znanstvene discipline, a, $s$ druge strane, ustrajao je u zalaganju da javnosti pokaže što psihologija jest a što nije. Bila su vrlo poznata njegova javna predavanja u Pučkom učilištu, toliko dobro posjećena da ih je morao ponavljati, kao i predavanja u studiju psihologije. Ramiro Bujas je uspio od psihologije u Hrvatskoj napraviti pravu respektabilnu znanstvenu disciplinu koja je bila čvrsti temelj za daljnji razvitak i znanstvene i primijenjene psihologije. O’Donnell (1985, prema Benjamin, 2007) napisao je: „Wundtova središnja uloga nije u nekom velikom otkriću nego u herojskoj propagandi eksperimentalizma". Ta tvrdnja jednako vrijedi i za Ramira Bujasa u našim prilikama.

\section{Elza Kučera}

Zasebno poglavlje u razvitku eksperimentalne psihologije u Hrvatskoj predstavljaju istraživanja Elze Kučera. Prvi objavljeni rad Elze Kučera nosi naslov „Psihogalvanska refleksna pojava prema svome značenju za psihologiju čuvstava“, a objavljen je u Nastavnom vjesniku, br. 23, 1914. godine. To je relativno opširan članak, u pretisku Kr. zemaljske tiskare iz Zagreba ima 25 stranica. Taj članak i danas - ako se uzmu u obzir razlike između početka 20. stoljeća i početka 21. stoljeća - može poslužiti kao uzor kako se pišu znanstveni izvještaji.

Fenomen kojim se bavila Elza Kučera nazvan je „Féréov efekt“ prema francuskom neurologu (1852.-1907.) koji je 1887. objavio knjigu posvećenu tom fenomenu.

Elza Kučera vrlo detaljno opisuje fizikalnu i fiziološku osnovicu „psihogalvanskog refleksa“ - u današnjoj terminologiji to je elektrodermalna reakcija. Svoje je eksperimente obavljala najvjerojatnije u vlastitom stanu, u kojemu je uredila mali laboratorij eksperimentalne psihologije 1912. godine. Prije toga Oton Kučera omogućio joj je da u Fizikalnom institutu Šumarske akademije započne s istraživanjima „zakonitosti u prijenosu čuvstava“.

Činilo mi se zanimljivim preslikati njezine grafikone (slika 4) i tablicu (tablica 1) rezultata iz 1914. godine. Ovako je Elza Kučera komentirala svoje grafikone: „Ako dakle na čovjeka, koji je uklopljen u struju, ne djeluju nikakvi izvanji podražaji, a subjektivno se što više smiri, pokazuje galvanometar, da se jakost struje u roku od 10-15 minuta konstantno smanjuje do nekog minimuma. Crtu, koja to grafički prikazuje, Veraguth naziva 'krivulja mirovanja. Ta krivulja nije kod različitih ljudi, a ni kod istog čovjeka u različito doba, posve jednaka ni onda, kad se radi s istim instrumentima u istom položaju, kad se dakle fizikalna komponenta pokusa može uzeti za konstantnu. U brzini se spuštanja i u dužini pojedinoga zastoja očituju individualne razlike." (lijevi grafikon na slici 4)

Elza Kučera je koristila nekoliko zvučnih podražaja (zvonce, udarac čekićem po stolu), ali nije dobila vidljivije promjene u otklonu galvanometra. Onda je provela ovaj pokus: „Između 4 i 5 sati poslije podne spustila se jakost struje kod 


\section{Tablica 1}

Rezultati Elze Kučera pri ispitivanju psihogalvanskog fenomena. U stupcu „Vrijeme“ označeno je točno vrijeme zadavanja podražaja, a u stupcu „Skala“" nalaze se rezultati izraženi u milimetrima na skali galvanometra.

\begin{tabular}{|c|c|c|c|}
\hline \multicolumn{3}{|c|}{ Vrijeme: } & Skala: \\
\hline & ata $35 \mathrm{~m}$ & nin. 0 sek & $75-$ hitac \\
\hline 4 & \#35, & 2 & 75 - per. latencije \\
\hline 4 & , 35, & 4 & 75 - per. latencije \\
\hline 4 & \#35, & $» 15 »$ & 90 \\
\hline 4 & $" 35$, & $” 30$ & 98 \\
\hline 4 & "35, & $” 45 »$ & 105 \\
\hline 4 & \#36, & $川 \quad-\quad$, & 115 \\
\hline 4 &, 36 , & $” 15 »$ & 116 \\
\hline 4 & \#36, & $\# 30 »$ & 116 \\
\hline 4 & $\Rightarrow 36$, & $” 45 »$ & 115 \\
\hline 4 & "37, & $" \quad-"$ & 112 \\
\hline 4 & \#37, & $\# 15 »$ & 110 \\
\hline
\end{tabular}

opažanika R. od 94 na 75 mm. Tada sam opalila mali dječji revolver, koji daje razmjerno vrlo jak prasak“. Rezultate koje je dobila prikazala je u tablici 1 (prepisanoj što vjernije; rezultati su izraženi na milimetaraskoj skali galvanometra). Rezultati drugog istraživanja prikazani su na desnom grafikonu na slici 4.

Pri kraju svog članka Elza Kučera raspravlja o mogućoj praktičnoj upotrebi „psihogalvanskog refleksa“ u kliničkoj praksi te kriminalistici.

Godine 1930. Elza Kučera objavila je u Archiv für die gesamte Psychologie, 77(1/2), (Leipzig), prilog „Experimentalle Beiträge zur Charakteristik der Willenshandlung" (Eksperimentalni doprinos karakteristikama voljnog djelovanja). Postavila si je pitanje: „Zbog čega se neke jednostavne reakcije ispitanika često opisuju kao voljno djelovanje, dok se neke uistinu izborne reakcije opisuju kao nešto 'mehaničko'?” Desetero svojih opažanika pitala je „po čemu je neko djelovanje za ispitanika voljno djelovanje, a određeni doživljaj voljni?" Nakon motorne reakcije tražila je od svojih opažanika da na temelju introspekcije opišu „ne samo svoje doživljaje, već i da navedu je li im se nešto učinilo voljnim djelovanjem,
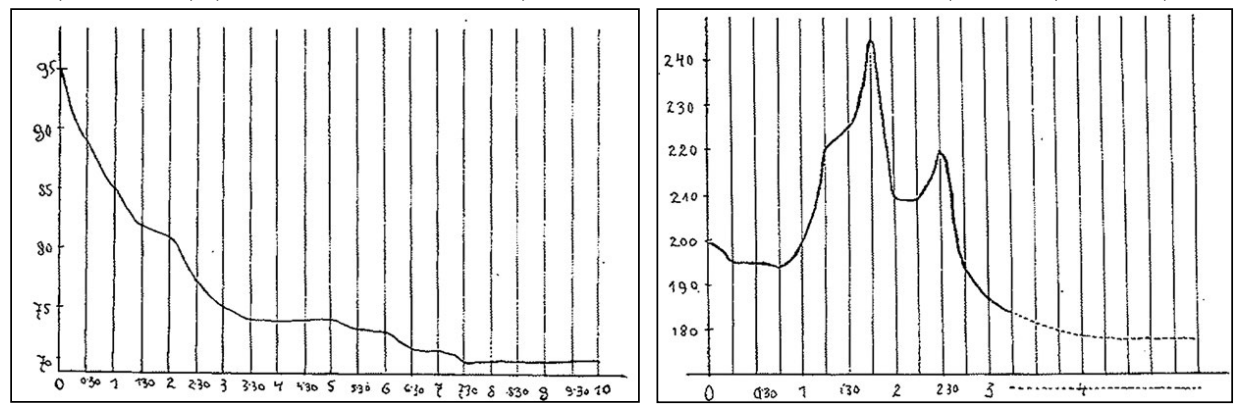

Slika 4. Preslik originalnih grafikona Elze Kučere. $\mathrm{Na}$ apscisi je vrijeme, a na ordinati su vrijednosti milimetarske skale galvanometra. 
ili ne i zašto“. Prema njihovim opisima navodi četiri kategorije: 1. Jednostavnu reakciju opažanici opisuju kao automatsku ili sasvim mehaničku, pri čemu nema govora o nečem voljnom, kada reakcija slijedi jako brzo; 2. podrobniji podaci o tome zašto se brze reakcije doživljavaju kao automatske opisani su u izjavama opažanika u kojima navode da su brze reakcije automatsko izvršavanje naloga, bez razmišljanja; 3. kao mehaničke opisuju se i reakcije kod kojih postoji određeno mišljenje ili doživljaj, ali se radnja odvija neovisno o tim mislima ili osjećajima; 4. automatskim se smatraju i reakcije u kojima kao da ,ja“ ne sudjeluje.

Ako zanemarimo terminologiju i interpretacije Elze Kučera, ovi njezini eksperimenti daju sasma drugačiju sliku pod vidom suvremenih istraživanja uma i svijesti. Rad je 1933. objavljen i u Acta Instituti psychologici Universitatis zagrabiensis, a 1947. objavljen joj je članak Eksperimentalni prilozi karakteristici motivacije u voljnom djelovanju.

Vrijedno je, čini mi se, osvrnuti se i na članak Elza Kučera „Osnutak psihologijskog instituta na višoj pedagoškoj školi“, objavljenu u časopisu Kršćanska škola 1923. godine koji je izlazio u Zagrebu od 1897. do 1945. godine. Tekst pokazuje kako se i Elza Kučera zalagala za psihologiju kao empirijsku znanost u tadašnjoj tomu nesklonoj intelektualnoj okolini i dobro ocrtava teškoće s kojima su se susretali svi koji su nastojali osamostaliti psihologiju u Hrvatskoj. Umjesto prepričavanja, evo opširnijeg citata:

Prije pedesetak se godina psihologija počela sve više cijepati od filozofije i izgrađivati kao čista empirijska nauka. I u području su se njezinoga istraživanja pokušala izvoditi mjerenja, a pomišljalo se i na upotrebu eksperimentalne metodologije, kojom su prirodne nauke baš u ono doba dolazile do svojih lijepih uspjeha. Weber i Fechner pokazali su prvi da se mjerenje, što se dugo vremena činilo oprečno naravi psihičkih fenomena, ipak može uz primjerene modifikacije uspješno upotrijebiti i za njihovo izučavanje. Mladi je filozof Wilhelm Wundt s oduševljenjem prihvatio te pobude i počeo $s$ mnogo energije da izgrađuje psihologiju kao eksperimentalnu nauku. Uz neprestanu živu polemiku s konzervativnim smjerovima osnovao je prvi institut za eksperimentalnu psihologiju najprije u Zürichu, a onda u Leipzigu. U njima je izvodio najprije psiho-fizička mjerenja i onda je pomalo uređivao i eksperimentalnu metodiku za izučavanje čisto psihičkih elementarnih pojava. Uspjeh za uspjehom govorio je njemu u prilog i budućnost je bila na njegovoj strani. Na različitim univerzitetima javljalo mu se sve više sljedbenika i jedan se psihologijski institut osnivao za drugim, najprije u Njemačkoj, a onda još gotovo bržim slijedom u svim drugim kulturnim zemljama. Iz područja elementarnih psihičkih fenomena počela je eksperimentalna metodologija da prelazi i u područje višsih i zamršenijih psihičkih tvorevina, a iz pojedinih su se istraživanja pomalo izvijale općene zakonitosti. Obnovljena je psihologija postala podlogom i pomagalom cijelome nizu drugih nauka. Na osnovi se psihologije najprije razvila eksperimentalna pedagogija, a pravne su i neke medicinske discipline crpile iz nje nove pobude i našle nova uporišta. $U$ posljednjim su se godinama napokon rezultati 
psihologije počeli iskorišćivati i u praktičnom životu. Organizacija rada, izbor zvanja prema psihičkoj organizaciji pojedinca, tehnika rasturivanja robe i reklame počela se na osnovi psihologijskih spoznaja ispitivati i reorganizirati. Uz psihologiju razvila se tako i na široko razgranala 'psihotehnika'. (...) Ali mimo nas je cijeli taj razvoj prošao gotovo neprimijećeno i bez ikakve reakcije u našem naučnom i praktičnom životu. (...) Ali u nas sve do sada đaci nisu imali prilike, da upoznadu ni najjednostavnije pomagalo za taj eksperimentalni rad; ni najjednostavniji im se niz psihologijskih eksperimenata nije mogao prikazati. (...) Tek godinu dana je tome, da ima i u našem sveučilištu docent za eksperimentalnu psihologiju, koji je pozvan da predaje i u višoj pedagoškoj školi. (...) ... (N)aredbom povjereništva za prosvjetu i vjere u Zagrebu od 30. ožujka o.g. (1922.? Op. V. K.) osnovan je napokon i oficijelno u višoj pedagoškoj školi prvi institut za eksperimentalnu psihologiju u našoj državi ili točnije rečeno, tom je naredbom dana službena podloga realizaciji takvog instituta.

Elza Kučera rođena je 1883. godine u Vinkovcima kao prvo dijete slavnoga hrvatskog prirodoslovca Otona Kučere. Umrla je 1973. u Zagrebu, mirno, samozatajno, od psihologa zaboravljena. Ženski licej završila je u Zagrebu 1902. godine. Godine 1902. i 1903. studirala je u Beču psihologiju i specijalnu filozofiju, ${ }^{17}$, a kod profesora A. Stöhra pohađalala je vježbe iz eksperimentalne psihologije. Od 1903. do 1905. godine studirala je na Mudroslovnom fakultetu Sveučilišta u Zagrebu psihologiju, specijalnu filozofiju i prirodne znanosti. Od 1905. do 1908. studirala je na Univerzitetu u Zürichu psihologiju, specijalnu filozofiju i fiziologiju. U Zürichu je surađivala s G. Störringom kod kojega je i doktorirala disertacijom s naslovom Die Erkenntnistheorie von Thomas Brown: eine historsische Studie (Teorija spoznaje Thomasa Browna: povijesna studija) 1910. godine. Thomas Brown (1778.-1820.), danas praktički zaboravljen, bio je škotski filozof, metafizičar. Skupina filozofa koju je on predvodio bila je usmjerena na osjetnu percepciju (Ecyclopedia Britannica, 2012, Kolesarić, 2011).

Prema Leksikonu filozofa (Grlić, 1982), Gustav Störring (1860.-1946.) bio je njemački psihijatar, psiholog i filozof, profesor u Zürichu i Bonnu. Njegova eksperimentalna psihološka istraživanja odnose se uglavnom na osjećajni život, psihologiju mišljenja i psihopatologiju. U svom članku Steinberg \& Künstler (2000) navode kako je Störringov boravak u Wundtovom laboratoriju eksperimentalne psihologije u Leipzigu imao vrlo velik utjecaj na njegov rad.

Elza Kučera, boraveći i studirajući u tadašnjim europskim intelektualnim metropolama, susrećući se i surađujući, u tadašnjem znanstvenom smislu, $s$ važnim osobama, imala je dobar uvid u burne tendencije u znanosti, pa se tako mogla oduprijeti standardnom filozofskom pristupu psihologiji. Zbog toga, iako je bila zanemarena, njezina eksperimentalna istraživanja značajna su za povijest eksperimentalne psihologije u Hrvatskoj.

17 Specijalnom filozofijom filozofi nazivaju dio filozofije koji se bavi etikom, estetikom, politikom, pravom i sl. 
Od 1933. do 1938. Elza Kučera bila je suradnik Ramira Bujasa u Psihologijskom institutu.

Godine 1909. bila je postavljena za pomoćnicu u Sveučilišnoj knjižnici, gdje je ostala raditi punih 35 godina. U hrvatskoj knjižničarskoj struci Elza Kučera zauzima značajno mjesto. ${ }^{18}$

\section{Zoran Bujas}

Postoje dva relativno opširna izdanja posvećena Zoranu Bujasu. Revija za psihologiju (Vol. 21, No. 1, 1991) izdala je poseban broj prigodom obilježavanja osamdesete obljetnice života i rada Zorana Bujasa. U tom se broju, osim njegove biografije i iscrpne bibliografije, nalaze i članci o njegovoj ulozi u razvitku Oddelka za psihologijo u Ljubljani (Gregorač, 1991); o njegovim istraživanjima u području psihofizike i osjetne psihologije (Szabo, Kolesarić \& Brenk, 1991); o njegovom mjestu i ulozi u pokušaju rješavanja bitnih pitanja psihofizike (Ognjenović, 1991); o istraživanjima u području psihofiziologije rada (Petz \& Vidaček, 1991); o konstrukciji psihologijskih mjernih instrumenata (Kulenović \& Krizmanić, 1991); o dokimološkim istraživanjima (Bartolović, 1991); o njegovom radu u području profesionalne orijentacije (Tarbuk \& Koren, 1991).

Drugo izdanje je spomenica posvećena preminulom akademiku Zoranu Bujasu (Sokač, 2005). Na šezdesetak stranica nalaze se tekstovi B. Petza, V. Kolesarića i Ž. Pavline u kojima se prikazuje život i rad Zorana Bujasa. I u ovom se izdanju nalazi potpuna bibliografija Zorana Bujasa. Postoji još članaka posvećenih Zoranu Bujasu kao što je, primjerice, onaj B. Petza (1983).

Zoran Bujas objavio je 161 istraživački rad. Među njima 54 rada su iz područja istraživanja okusa, 5 se bavi električnim fosfenima i još 17 njih bavi se različitim drugim pitanjima psihofizike i osjetne psihofiziologije (ukupno 76). Dakle, oko $47 \%$ radova Zorana Bujasa su radovi tipično eksperimentalne naravi, tj. temelje se na eksperimentima provođenima u laboratorijskim prilikama.

Najveći dio članka u Reviji za psihologiju autora Szabo, Kolesarić i Brenk (1991) posvećen je istraživanjima Zorana Bujasa u području okusa. Članak završava konstatacijom da su rezultati proučavanja Zorana Bujasa u području okusa, dobiveni korištenjem rigorozno elaborirane metodologije, bitni za objašnjenje naravi funkcioniranja okusnog sustava. To osobito jasno pokazuje činjenica da nema članka ili zbornika ili knjige koji se bave područjem okusa a da nisu citirani radovi Zorana Bujasa (primjerice, povjereno mu je pisanje poglavlja „Electrical Taste" u poznatom višesveščanom priručniku Handbook of Sensory Physiology; Bujas, Z., 1971) (Pavlina i Kolesarić, 2005). Eksperimente u području okusa i električnog okusa Zoran Bujas provodio je sa svojim suradnicima, npr. Bujas, Ajduković i Mayer, 1984; 1987; Bujas, Ajduković, Szabo, Mayer, Vodanović 1985; 1986; 1987; 1994; 1995. Najviše su sa Zoranom Bujasom u tom području

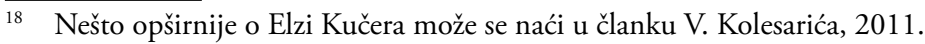


surađivali Silvija Szabo, koja je doktorirala s temom Utjecaj postepenog porasta $i$ trajanja podražaja na apsolutnu osjetljivost u području električnog okusa (1976), zatim Dean Ajduković, koji je magistrirao s temom Površina elektrode i električni okus i doktorirao s temom Utjecaj nekih karakteristika električnog podraživanja jezika na supraliminalne senzorne efekte (1982) te Božica Bartolović koja je magistrirala s temom Brzina porasta intenziteta podražaja u vremenu i neki aspekti funkcionalne sposobnosti okusnog analizatora (1977).

Začetak eksperimentalne psihologije nalazi se u psihofizici. A psihofizika zahvaljuje svoj nastanak pokušaju rješavanja vječnog filozofskog pitanja odnosa fizičkog i psihičkog. Upravo taj problem dualizma naveo je Gustava Fechnera (1801.-1889.) na ideju o mjerenju odnosa između fizičkog i psihičkog. Ta mjerenja pokazala su da fizički i psihološki svijet nije isti i, kako kaže Benjamin (2007), kad bi bili isti, psihologije nam ne bi ni trebalo.

Kombinirani naziv psihofizika opisuje u kakvom je odnosu doživljavanje prema promjenama u fizičkom svijetu. Psihofizika ne traži neku osobu da objasni svoj doživljaj crvenog, nego traži odgovor na pitanje: da li različiti ljudi doživljavaju crveno za isti fizički podražaj? (Kranz, 2008).

Fechenrova misija je bila filozofska i psihofizika je bila nusprodukt njegove filozofije, odnosno neposredni rezultat Fechnerove ideje bila je formulacija programa koji je kasnije nazvan psihofizika. Razvijene su metode mjerenja, tri psihofizičke metode koje su postale temeljne za mnoga psihologijska istraživanja. Utvrđeni su matematički oblici i za metode i za objašnjenja općeg problema mjerenja. Obavljeni su klasični eksperimenti s podizanjem utega, vidnim svjetlinama te taktilnim i vidnim udaljenostima. Tome je pripomoglo studiranje i Fechnerovo bavljenje fizikom - jedno je vrijeme bio u Leipzigu profesor fizike (Boring, 1950).

Istina je da je dominantni interes Zorana Bujasa bila psihofizika, ali njegovi interesi bili su širi, a najvažnija područja, osim psihofizike, bila su psihofiziologija rada, dokimologija i psihometrija. U području psihofiziologije rada, Zoran Bujas je, zajedno sa suradnicima, proveo mnogo vrlo važnih eksperimenata ispitujući psihološke aspekte rada, umora i odmora.

Posebice treba istaknuti psihometrijsko područje, tj. područje konstrukcije novih psihologijskih mjernih instrumenata, gdje se izrazito ističe velik broj sasvim novih, inovativnih i kreativnih testova inteligencije.

No, Zoran Bujas je počeo i završio svoj dugotrajni istraživački vijek s osjetnom psihologijom i psihofizikom. Naslov njegove doktorske disertacije bio je $O$ sukcesivnom kontrastu kod okusa, 1933., koja nije objavljena. Od 15 radova, koje je objavio između 1932. i 1937. godine, samo dva se ne odnose na osjetnu psihofiziologiju. Sva 22 rada objavljena između 1983. i 1991. su iz područja osjetne psihofiziologije, kao i zadnji rad objavljen 1999. (Bujas, Ajduković, Szabo, Mayer, and Matutinović, 1999).

Zoran Bujas je u svojim istraživanjima osjetne psihofiziologije koristio, moglo bi se reći, sve psihofizičke metode: od klasičnih, (npr. metoda konstantnih 
podražaja), novijih (npr. metoda prisilnog izbora s dva podražajna intervala, nastala u okviru teorije detekcije signala), još novijih (različiti oblici Stevensove subjektivne procjene veličina) te vrijeme jednostavne senzomotorne reakcije kao kriterij djelotvornosti osjetnog podražaja.

Ali, budući da mu je uvijek bilo neobično stalo do valjane metodologije, do valjanog prikupljanja podataka, Zoran Bujas je unosio u metodologiju i neke inovacije.

Jedna od tih inovacija bio je i stupanj deklarirane sigurnosti koji se prikuplja prilikom korištenja neke od psihofizičkih metoda, najčešće uz metodu prisilnog izbora s dva opažajna intervala. Taj postupak - prikupljanje izjave o stupnju sigurnosti u odgovor - Zoran Bujas je koristio u više radova: Bujas, 1975; Bujas, Kovačić i Rohaček, 1975; Bujas, Krizmanić i Krković, 1975; Bujas, Rohaček, Kovačić, 1975; Bujas, Rohaček and Szabo, 1977. Tom metodom bavili su se posebno i suradnici Zorana Bujasa: Szabo, 1973, 1977; Brenk, 1977; Kolesarić 1979; 1983; 1987).

Najboljom suvremenom psihofizičkom metodom smatra se upravo metoda prisilnog izbora s dva simetrična opažajna intervala, na prvom mjestu zato što se smatralo, kako se kasnije pokazalo ne sasvim opravdanim, da se tom metodom anulira različit kriterij opažanika. Postupak se sastoji u prezentiranju u kratkoj sukcesiji dva opažajna intervala, u jednom se nalazi podražaj nekog intenziteta, a drugi je prazan, tj. u njemu nema nikakvog podražaja (redoslijed opažajnih intervala, prvi prazan, drugi s podražajem, ili obrnuto, po slučaju se alterira u eksperimentu). Nakon njihova prezentiranja, opažanik se mora opredijeliti za jedan od intervala i tako odgovoriti na zadatak utvrđivanja u kojem se intervalu nalazio podražaj. Rezultati dobiveni ovom metodom, kao i drugim psihofizičkim metodama, najčešće se prikazuju tzv. psihofizičkom funkcijom koja ima sigmoidni oblik. Sigmoidni oblik psihofizičke funkcije predstavlja, ustvari, integral normalne krivulje, što znači da vrijednosti koje čine krivulju slijede normalnu distribuciju.

Psihofizičkim metodama dobivaju se binarni odgovori koji se kumuliraju te se na temelju njih određuje korespondentni intenzitet osjetnog doživljaja za svaku intenzitetnu razinu podraživanja. Tako se i pri primjeni metode prisilnog izbora dobivaju samo informacije o tome je li - prema sudu opažanika - u određenom opažajnom intervalu bio prisutan podražaj ili nije. Međutim, takav odgovor ne pokazuje koliki je bio senzorni učinak primijenjene intenzitetne razine podražaja na temelju kojega je opažanik donio svoju odluku. Svoj psihofizički sud opažanik donosi s manjom ili većom sigurnošću. Ako se od opažanika traži da deklarira svoju sigurnost u odgovor koji je dao, ona će ovisiti o jasnoći senzornog učinka. Osim toga, deklarirana sigurnost opažanika odražavat će i kriterij koji opažanik ima pri donošenju svojih odluka. Kod svih psihofizičkih postupaka, pa čak i kod metode prisilnog izbora, pitanje kriterija koji opažanik ima pri psihofizičkom suđenju predstavlja faktor koji šteti valjanosti rezultata. Taj faktor izravno djeluje na dobivene rezultate, jer će opažanik koji će, čim mu se učini da je nešto vidio ili čuo, odmah 
dati pozitivan odgovor, dok će neki drugi tek kad je vrlo siguran u svoj doživljaj, dati svoj odgovor. Stoga je podatak o kriteriju opažanika vrlo važan podatak.

Obično se traži od opažanika da svoju sigurnost izrazi na ljestvici od „nula“ do „sto“: odgovor „nula“ znači da se uz dani odgovor veže potpuna nesigurnost, odgovor je, zapravo, obično pogađanje je li podražaj bio u prvom ili u drugom opažajnom intervalu. Odgovor „sto“ znači da je opažanik potpuno siguran u svoju odluku. Naravno, vrijednosti između nula i sto znače manju ili veću sigurnost ili nesigurnost. Zoran Bujas je predložio da se na temelju takvih odgovora opažanika odredi $\beta$-indeks: za svaku intenzitetnu razinu podražaja izračuna se prosječan stupanj sigurnosti za svaku intenzitetnu razinu podražaja i za svakog opažanika zasebno, bez obzira radi li se o promašajima ili pogodcima, pa je zbog takvog određivanja taj indeks nezavisan o broju detekcija. Na temelju vrijednosti $\beta$-indeksa može se konstruirati svojevrsna psihofizička funkcija, koja također ima sigmoidni oblik: u grafičkom prikazu te funkcije na apscisi nalaze se podražajni intenziteti, a na ordinati $\beta$-indeks za svaku razinu (Kolesarić, 1983; Kolesarić, 1987). Jedan takav primjer nalazi se na slici 5 .

Stupnjevi sigurnosti nisu sasvim originalna Bujasova ideja (npr. Koriat, 2011), ali je ideja o njihovoj upotrebi pri psihofizičkom suđenju vrlo korisna i proširuje smisao psihofizičkih rezultata. Prvo, pokazuje nam kriterij - blaži ili stroži opažanika pri donošenju odluka. Drugo, opažanici se - sudeći prema spontanim

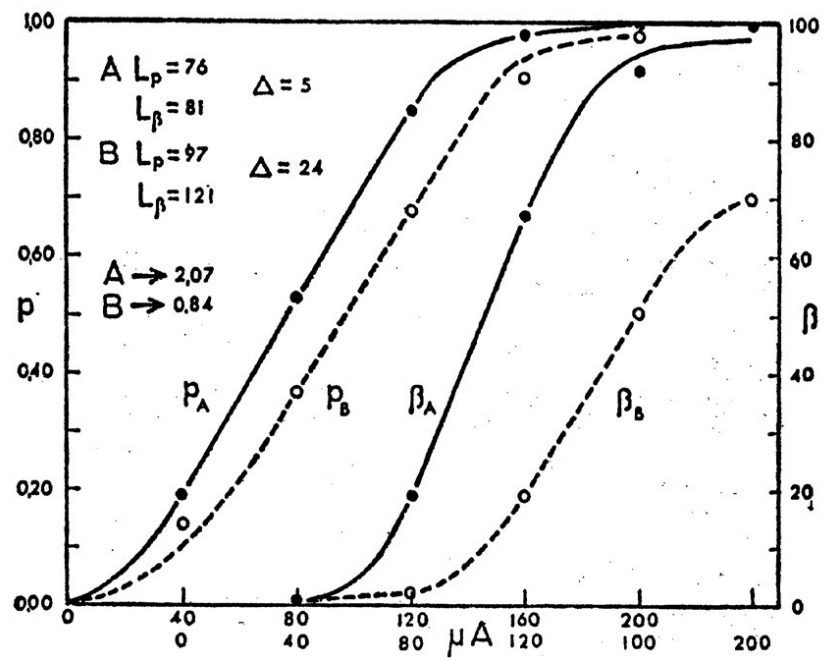

Slika 5. Psihofizičke funkcije, dobivene proporcijama detekcije za svaku podražajnu razinu, jednog „blažeg“ (na grafikonu označeno $s \mathrm{p}_{\mathrm{A}}$ ) i jednog „strožeg“ (na grafikonu označeno $s \mathrm{p}_{B}$ ) opažanika. Vrijednosti na apscisi pomaknute su u desno kako bi se krivulje dobivene proporcijom pogodaka i $\beta$-indeksom mogle prikazati usporedno na jadnom grafikonu: $\beta_{A}$-indeks dobiven je uz $\mathrm{p}_{\mathrm{A}}, \beta_{\mathrm{B}}$-indeks uz $\mathrm{p}_{\mathrm{B}}$. Lako se vidi kako je kod strožeg opažanika psihofizička funkcija stupnjeva sigurnosti izrazito pomaknuta prema većim vrijednostima (udesno), puno više nego što je to kod blažeg opažanika. (Kolesarić, 1987). 
izjavama opažanika koji su sudjelovali u takvim eksperimentima - osjećaju udobnije: pogađanje u kojem se intervalu nalazio podražaj traži od opažanika određen napor kad se radi o slabim podražajima. Izjavom o stupnju sigurnosti u takvim slučajevima opažanik se na neki način zaštićuje.

Korištenje stupnjeva sigurnosti u psihofizičkom suđenju predstavlja određeni iskorak Zorana Bujasa. Njegova istraživanja uvijek su se temeljila na „tvrdoj“ metodologiji. Legendarna je njegova opreznost i u prikupljanju podataka i u njihovoj interpretaciji. Uvođenjem stupnjeva sigurnosti Zoran Bujas je pokazao kako je poznavao tipičan ljudski način reagiranja na senzorne (ali i druge) podražaje: donosimo odluke kad smo na neki način uvjereni u sigurnost te odluke, a jasno je da postoje velike individualne razlike u stupnju sigurnosti uz koje će netko „prijeći s riječi na djela“; nekome je dovoljan tek mali stupanj uvjerenja, a nekome vrlo velik. Za odluku, čak i u takvim jednostavnim prilikama kao što je psihofizički eksperiment, sam senzorni efekti nije dostatan da bi omogućio efikasnu odluku. Metodom prisilnog izbora opažanici su doista „prisiljeni“ odlučiti se za jedan od opažajnih intervala, ali to još uvijek ne mora značiti da će i djelovati prema takvom rezultatu. Za djelovanje odlučan je stupanj sigurnosti.

U jednom radu (Bujas, Krizmanić, Krković, 1975) korišteni su stupnjevi sigurnosti i pri primjeni kognitivnog testa.

Najnovija istraživanja pokazuju kako su slutnje Zorana Bujasa bile ispravne. Koristiti deklarirane stupnjeve sigurnosti dodatni je podatak, to nije podatak koji samo prati odgovore opažanika pri primjeni psihofizičkih metoda.

Zoran Bujas i suradnici (1980) ispitivali su da li različit opseg podražaja pri procjenjivanju metodom direktnih procjena intenziteta podražaja stvarno mijenja senzorni efekt podražaja ili samo utječe na kriterij prosudbi subjekta. Konkurentno su prikupljali podatke snimanjem evociranih potencijala i registriranjem subjektivnih procjena intenziteta slušnih podražaja. Subjektivne procjene podražaja u užem i širem nizu podražaja (zapravo se radi o podražajnom nizu s manjim brojem podražaja i s većim brojem podražaja, a najmanji i najveći podražaj u oba niza su jednaki) bitno se razlikuju (bitna je razlika u strmini dobivenih krivulja), dok se amplitude evociranih potencijala ne razlikuju za ove nizove. Autori završavaju članak komentarom Watsona kojega citira H. Davis: ${ }^{19}$ „Ako se radi o stanju svijesti kooperativne osobe, informacije iz njezinih usta su mnogo bolje nego $s$ vrha njegove glave“.

Zoran Bujas je polazio upravo od pretpostavke da kontinuum senzornog doživljaja intenziteta podražaja i kontinuum prosudbe nije isti kontinuum. To je, pretpostavljam, bio razlogom (ili barem jedan od razloga) za korištenje stupnjeva

19 Davis, H. (1974). Relations of perpheral action potentials and cortical evoked potentials to the magnitude of sensation. In: H.R. Moskowitz et al. (Ed.), Sensation and measurement. Dortreht: Reidel. 
sigurnosti uz odgovor u psihofizičkim mjerenjima. Tri su autora , J. Heereman, H. Walter i H. R. Heekeren (2015) relativno nedavno pokazali (oni smatraju da su i dokazali), koristeći kombinaciju dviju perceptivnih odluka sa snimanjem funkcionalne magnetske rezonancije (fMRI), da je subjektivna sigurnost u odluku nezavisna neuralna reprezentacija. Do takvog zaključka došao je i Zoran Bujas, ali ovi su autori koristili noviju i napredniju tehnologiju - pa, eto, i to pokazuje kako su psihologijske spoznaje ovisne i o tehnologiji.

Zoran Bujas uvijek je nastojao dobiti podatke o istoj senzornoj pojavi na različite načine, različitim postupcima i pristupima. Tako je, osim tzv. adekvatnog podraživanja, koristio prilično često i tzv. inadekvatno podraživanje, i to i u području okusa i u području vida. Istraživači u svijetu napravili su doista brojna istraživanja s inadekvatnim podraživanjem, a najčešće su se koristili električnom strujom (slabom, dakako). Najviše je istraživanja napravljeno u području električnog okusa, električnih fosfena ${ }^{20}$ te u području električki izazvanih dodirnih osjeta. Električna struja, bilo izmjenična, bilo istosmjerna, koristi se zbog dvaju razloga. Tako, primjerice, u području vida usporedbom adekvatnog (svjetlosnog) podraživanja i inadekvatnog (električnom strujom) podraživanja može se utvrditi ekscitiraju li svijetlo i električna struja iste ili donekle različite strukture osjetnog organa. Budući da se pretpostavlja da električna struja preskače periferne dijelove osjetnog organa, kod vida to su osjetne vidne stanice štapići i čunjić, i da djeluje na živčane dijelove retine oka, bipolarne stanice, pa i amakrine i horizontalne stanice, nalazi dobiveni inadekvatnim podraživanjem mogu obogatiti spoznaje o općem funkcioniranju vidnog organa. Ali i općenitije, s obzirom na način funkcioniranja vidnog analizatora kao cjeline, istraživanja električnih fosfena mogu pomoći da se dođe do nekih spoznaja o ulozi pojedinih etapa, od periferije do centra, u nastajanju vidnih osjeta. Uloga nekih perifernih faza (kao što su to npr. fotokemijski procesi u receptorskim stanicama) relativno je poznata, ali za mnoge fenomene u području vida nije sasvim jasno jesu li odgovorni središnji ili periferni procesi ili i jedni i drugi. Eksperimenti koje je proveo Zoran Bujas i njegovi suradnici pokazali su da se električni fosfeni doživljajno razlikuju od fenomena koji postoje pri normalnom svjetlosnom podraživanju. Tako je, primjerice, krivulja rekuperacije električki izazvanih fosfena monotona, za razliku od krivulje rekuperacije nakon svjetlosnog podraživanja koja je, kako je poznato, prelomljena, tj. sastoji se od dva dijela: bržeg (rekuperacija čunjića) i sporijeg (rekuperacija štapića) (Kolesarić, 1979; Kolesarić, 1981).

Zoran Bujas i njegovi suradnici bavili su se temeljnim pojavama u području električki izazvanih fosfena, dok se u suvremenoj literaturi javljaju uglavnom istraživanja koja se bave pitanjem korištenja električkih fosfena u patološkim

$\overline{20}$ Fosfeni su nestrukturirani vidni doživljaji izazvani inadekvatnim podražajima. Mogu biti mehanički izazvani, npr. pritiskom na očnu jabučicu ili udarcem u glavu ili glavom ili primjenom vrlo slabe električne izmjenične ili istosmjerne struje. 
slučajevima, tj. pitanjima može li korištenje električnih fosfena koristiti u dijagnostici nekih očnih bolesti ili/i neuroloških bolesti (npr. Naycheva, L. et al. (2012). Phosphene thresholds elicited by transcorneal electrical stimulation in healthy subjects and patients with retinal diseases, Visual Psychophysics and Physiological Optics, 53(12); Kar, K. \& Krekelberg, B. (2012). Transcranial electrical stimulation over visual cortex evokes phosphenes with retinal origin, J Neurophysiol, 108(8). Postoje i pokušaji da se koriste kao sredstvo komunikacije kod slijepih osoba $s$ određenom etiologijom sljepoće.

Drugi razlog proširenom korištenju električne struje kao podražaja u psihofizičkim eksperimentima je lako i udobno manipuliranje tim podražajnim sredstvom.

Posebno je interesantan rad Zorana Bujasa (i suradnika) (1980) koji počinje ovom rečenicom: „Interes psihologa za probleme koji se ne mogu riješiti isključivo bihevioralnim mjerenjem na fizikalnim skalama doveo je do rehabilitacije subjekta kao izravnog izvora psiholoških informacija“. Tu se, očito na prvom mjestu misli na Stevensovu „subjektivnu“ ili „novu psihofiziku“. Zoran Bujas inicirao je veći broj istraživanja koja je uglavnom provela Silvija Szabo (1967., 1972., 1973.), a u kojima su provjeravana svojstva poznatih Stevensovih metoda direktnih procjena veličina: subjektivna prosudba veličine podražaja pridjeljivanjem numeričkih vrijednosti osjetnom doživljaju koji je određeni podražaj izazvao. Provjere različitih varijanti te metode (sa standardom, bez standarda, uži raspon podražaja, širi raspon podražaja itd.) pokazale su da se sa svakom promjenom načina mjerenja subjektivnih veličina dobivaju manje-više drugačiji rezultati.

Zoran Bujas je doista puno svoje istraživačke pažnje posvećivao metodologiji, tj. valjanosti postupaka koji su mu služili za dobivanje relevantnih podataka. Eksperimenti sa Stevensovim direktnim brojčanim procjenama intenziteta podražaja, između ostalog, pokazali su kako podražajni kontekst - razina podražajnog niza, opseg podražajnog niza, i slične promjene u podraživanju - može imati značajnog utjecaja na rezultate, tj. na odgovore opažanika. Do sličnih uvida Zoran Bujas došao je koristeći naizgled objektivniji kriterij efikasnosti senzornog podražaja - vrijeme jednostavne senzomotorne reakcije. U članku iz 1975. Zoran Bujas kritički raspravlja o tzv. tvrdoj psihologiji, pa, između ostalog piše kako se obično izjave opažanika tijekom psihofizičkih pokusa, koje su neočekivane prema mišljenju eksperimentatora, smatraju posljedicom očekivanja opažanika, pogađanjem, njegovim konfabuliranjem ili izmišljanjem. Budući da je tijekom eksperimentiranja uvijek brižljivo pratio dobivanje rezultata, primijetio je kako je i vrijeme jednostavne senzomotorne reakcije - kojim se izbjegava verbalni odgovor podložan mnogim subjektivnim utjecajima - također podložan u stanovitoj mjeri nekim subjektivnim čimbenicima. Ali, već je i, koristeći (najbolju) psihofizičku metodu prisilnog izbora $s$ dvije simetrične alternative, Zoran Bujas bio upoznat $s$ teorijom detekcije signala u kojoj se upravo tražilo da se doživljajna djelotvornost senzornog signala vrednuje u odnosu na kontekst koji je nazvan buka ili šum. 
Tako je Zoran Bujas na neizravan način potaknuo svoje suradnike na istraživanja podražajnog konteksta, kao i na provjeravanje utjecaja subjektivnih faktora na vrijeme jednostavne senzomotrne reakcije. Primjerice: Kolesarić i Rohaček, 1984., Kolesarić, Rohaček i Komar, 1984.; Kolesarić, Krizmanić i Špehar, 1986.; Ivanec, 1996.

No, vratimo se na početak. Psihofizika je nastala kao posljedica težnje rješavanja odnosa psihičkog i fizičkog odnosno, zapravo, kao gnoseološki problem (P. Ognjenović, 1991), a time se bavio Zoran Bujas. Premda nikad svoju temeljnu motivaciju nije eksplicirao, pokazao ju je uspoređujući tzv. klasičnu psihofiziku i tzv. novu, subjektivnu psihofiziku, te raspravljajući o teoriji detekcije signala. Odnosno, tražeći dokaze za Fechnerov psihofizički zakon nasuprot Stevensovom psihofizičkom zakonu (Z. Bujas, 1972.). Kako je dobro poznato, Fechenerov zakon se često naziva i logaritamski zakon prema kojemu je krivulja odnosa u kartezijanskom koordinatnom sustavu zakrivljena, ili opisno, to je krivulja negativne akceleracije, što znači da je skala doživljenih intenziteta podražaja u odnosu na intenzitete podražaja komprimirana.

Stevensov zakon se naziva i potencijalnim zato što je Stevens tvrdio da odnos između intenziteta senzornog podražaja i intenziteta izazvanog osjetnog doživljaja najbolje opisuje potencijalna funkcija kod koje eksponent može biti veći od 1, može biti 1, a može biti i manji od 1, ovisno o senzornom modalitetu. Stevens je napravio i tablicu u kojoj se navode eksponenti za različite senzorne modalitete: npr. za podizanje utega eksponent iznosi 1.45, za električni šok - neopasni, dakako - iznosi 3.5, kod okusa za saharin 0.8 , za sol 1.4 , kod mirisa 0.6 , kod svjetlina između 0.33 i 1.0 itd. (MacKay, 1963.; Staddon, 1978). Kad je eksponent veći od 1, tada bi s porastom intenziteta podražaja intenzitet osjetnog doživljaja rastao ubrzano; kad je eksponent 1 , tada je odnos intenziteta podražaja i intenziteta osjeta linearan, a kad je eksponent manji od 1, tada intenzitet osjeta raste usporeno, zaostaje za porastom intenziteta podražaja, kako to predviđa Fechnerov logaritamski zakon.

U članku „Psihofizika nekad i danas“ Zoran Bujas (1972) piše da bi prema indirektnim metodama (Fecherova psihofizika) skaliranja postojao za sva osjetna područja i za sve opažanike jedan jedinstveni psihofizički odnos prema kojemu osjetni „izlaz“ zaostaje za podražajnim ulazom, za razliku od podataka dobivenih direktnim metodama skaliranja (Stevensova psihofizika) prema kojima neke opće zakonitosti nema: psihofizički odnos može biti „kojekakav, već prema vrsti podražaja i aktiviranom receptoru, ali nažalost i prema individualnom opažaniku“.

Prema klasičnoj psihofizici senzorna osjetljivost je diskontinuirana i apsolutni limen ili prag osjetljivosti predstavlja demarkacionu (statističku) točku između neosjećanja i osjećanja. Prema teoriji detekcije signala senzorna osjetljivost je kontinuirana i stvarna djelotvornost nekog podražaja može se jedino odrediti na temelju razlike u efektu signala u odnosu na efekt slučajnih procesa u osjetnom 
kanalu, a to je šum. U radu „Kriteriji efikasnosti signala u psihofizici“ Zoran Bujas (1975) koristeći električne fosfene pokazuje da senzorna osjetljivost stvarno nije kontinuirana već diskontinuirana, kako tvrdi klasična psihofizika.

Ne samo za psihologiju, već i na široj, gnoseološkoj razini, pitanja kodiranja intenzitetnih i kvalitativnih svojstava svijeta u kojemu je čovjek uronjen, kao pitanje doživljaja koje djelovanje okoline izaziva, čime se bavi psihofizika, bitna su spoznajna pitanja.

Pri kraju članka o Zoranu Bujasu i psihofizici P. Ognjenović (1991) piše kako se u dvije tisuće godina raspravljanja o tome da li se vanjski svijet reflektira u našem umu, kao što je to vjerovao Demokrit, ili se naš um pruža prema vanjskom svijetu kako bi stekao znanje o njemu, kako bi ga „osjetio“, kao što je zaključivao Empedoklo. Za Zorana Bujasa smatra da se priklonio Demokritovom mišljenju. No, ipak, to mišljenje treba nadopuniti tvrdnjom Zorana Bujasa u članku „Pojave osjetne adaptacije“ (1973) da je pojava osjetne adaptacije aktivno prilagođavanje osjetnog organa podražaju, pa, možda, ima tu i Empedoklovog mišljenja.

\section{Zagrebački psihologijski krug}

Mnogi su se, iz bližeg ili daljeg okruženja Ramira Bujasa i Zorana Bujasa, pitali - osobito zato što se Bujasi o tome nikada nisu otvoreno izjašnjavali - kojem smjeru, kojoj psihologijskoj školi oni pripadaju. Povremeno se govorilo o „zagrebačkom psihologijskom krugu" koji je i sam Zoran Bujas povremeno spominjao, ali, zapravo, nije sasvim jasno na što bi se taj termin odnosio, osim na rigorozan pristup istraživanjima i izraziti oprez u zaključivanju o dobivenim rezultatima. Radi se, zapravo, o neprestanom isticanju da znanstveni podatak može biti valjan i pouzdan samo ako je dobiven provjerenim znanstvenim metodama i tehnikama, jer jedino takav pristup može garantirati znanstvenu, ali i praktičnu vrijednost rezultata istraživanja (Kolesarić i Pavlina, 1990; Pavlina i Kolesarić, 2005).

Je li Ramiro Bujas bio sklon biheviorizmu ili, možda, onom pravcu koji je nazvan neobiheviorizmom, ili tzv. metodologijskom biheviorizmu? Ni za Ramira ni za Zorana Bujasa, iako bi se njihova istraživanja naizgled mogla označiti kao bihevioristička, ne bi se moglo reći da su bihevioristi; ako je kod njih postojala neka sklonost u tom smjeru onda je to, možda, u smjeru metodologijskog biheviorizma. ${ }^{21}$ To se može lako zaključiti iz definiranja i opisivanja psihologije i njezine metode. Primjerice u knjizi Dobivanje psihologijskih podataka i njihovo računsko obradivanje, objavljenoj 1942. godine, Ramiro i Zoran Bujas pišu:

$\overline{21}$ Metodologijski biheviorizam je oblik biheviorizma koji priznaje postojanje i realitet svjesnih doživljaja ali tvrdi da je jedini prihvatljiv način njihova znanstvenog proučavanja temeljem njihovog izražavanja u ponašanju. 
„Prvi i najjednostavniji postupak je samoopažanje subjekta. Taj se postupak osniva na 'nutarnjem' zamjećivanju, po kojemu se davno prije svake psihologije znalo da postoji područje pojava, koje su očite samo onome, koji ih doživljava. Ali takvo slućajno zamjećivanje koje bismo mogli nazvati introvizijom, nije još metoda. $Z a$ tu svrhu je potrebno aktivno opažanje ili opservacija svog doživljaja uz neke stalne prilike i sa znanstvenim ciljem. Na taj način mjesto slučajne introvizije imamo namjernu introspekciju ili samoopažanje. Introspekcija je osnovna pretpostavka za svako psihologijsko istraživanje. Ipak ona može udovoljiti zahtjevima psihologijske znanosti samo uz posebne mjere opreznosti $i$ kontrolu."

U Elementima psihologije iz 1945. Zoran Bujas piše: „Pri opisivanju i tumačenju duševnih pojava psihologija se uglavnom služi dvjema metodama: subjektivnom metodom ili samoopažanjem i objektivnom metodom ili zaključivanjem iz vanjskih znakova“, i dalje „Da nema samoopažanja ne bismo uopće znali, da postoji duševni život i ne bismo imali ključa, po kojemu bismo mogli iz ponašanja drugih izvoditi zaključke o njihovu duševnom životu“.

I, zatim, u Uvodu u metode eksperimentalne psihologije Zoran Bujas (1981), u poglavlju „Osnovne metode psihologije“, piše „Budući da se psihički fenomeni očituju iznutra subjektu kao kvalitativno svojevrsni red pojava, dok se izvana objektivno očituju kao načini ponašanja i djelovanja, to se metode psihologije dijele prema osnovnom načinu opažanja (unutarnjem ili vanjskom) na introspekciju i ekstrospekciju“. I, osim toga, Zoran Bujas prikazuje istraživačku shemu $\mathrm{P}=\mathrm{f}(\Psi / \mathrm{n} S)$, gdje $\mathrm{P}$ označuje ponašanje, $\Psi / \mathrm{n}$ psihonervnu aktivnost i $S$ podražajnu situaciji. Dakle, ponašanje je funkcija djelovanja psihonervne aktivnosti i okoline.

Čini se da se mirno može zaključiti da Bujasi nisu bili bihevioristi, pa ni neobihevioristi. ${ }^{22}$ Rigorozno inzistiranje na preciznim definicijama predmeta mjerenja i preciznom kontrolom procesa mjerenja upućuje, možda, na operacionalizam, ${ }^{23}$ osobito stoga što je Zoran Bujas često isticao kako dobar istraživač u psihologiji mora dobro poznavati fiziku ili barem optiku, akustiku i elektricitet. ${ }^{24} \mathrm{Na}$ to bi mogli upućivati neki radovi Zorana Bujasa, npr. Z. Bujas, 1935; Z. Bujas, 1937. Međutim, to bi bila pomalo nategnuta klasifikacija, jer bi se tako svakog rigoroznog istraživača moglo nazvati pristalicom operacionalizma.

22 Neobiheviorizam se naziva orijentacija u psihologiji koja počiva na biheviorizmu, a opća joj je karakteristika da shemu „klasičnog“ ili „radikalnog“ biheviorizma $S-R$ proširuje na $S-O-R$, tj uvodi unutrašnje ili organske varijable (intervenirajuće varijable, hipotetički konstrukti) (Petz, 2005).

23 Operacionalizam: nazor po kojem stajališta znanosti, njezini zakoni i pojmovi, ne postoje sami po sebi, već samo u okvirima znanstvenih postupaka u kojima se potvrđuje ili poriče njihovo postojanje. Kao filozofijsko-znanstvenu doktrinu operacionalizam je utemeljio američki fizičar P. W. Bridgman (Hrvatska opća enciklopedija, 2006).

24 Sve do otprilike sredine osamdesetih godina prošlog stoljeća obavezni kolegij u prvoj godini studija u Odsjeku za psihologiju Filozofskog fakulteta bio je „Optika, akustika i elektricitet“, koji je dugo godina predavao profesor Dragutin Mayer. 
Moje je mišljenje, ipak, da su i Ramiro Bujas i Zoran Bujas bili, zapravo, na neki način preteče onoga što danas nazivamo kognitivnom psihologijom.

\section{Nakon Ramira Bujasa, Elze Kučera i Zorana Bujasa}

Psihologija u Hrvatskoj, kako su je impostirali Ramiro i Zoran Bujas, pa i Elza Kučera, jest na prvom mjestu empirijska psihologija i toga se drže - manje-više - svi psiholozi, i istraživači i praktičari u Hrvatskoj, bilo da su njihovi izravni ili neizravni sljednici, bilo da provode laboratorijska istraživanja ili istraživanja in situ, odnosno u tzv. prirodnim uvjetima, bilo da se koriste vrlo različitim psihologijskim metodama - uvijek se može vidjeti nastojanje da se što preciznije, sa što manje „šuma“ obave istraživanja, kako bi se dobili što valjaniji podaci. To je svakako popudbina ovih stožernih ličnosti u povijesti hrvatske psihologije.

Uvodeći eksperimentalnu psihologiju u Hrvatsku znanstvenu zajednicu, najprije Ramiro Bujas, a zatim Zoran Bujas, uveli su način znanstvenog mišljenja koji - kako je općenito poznato - omogućuje dobivanje podataka koji su najmanje kontaminirani subjektivnim čimbenicima pa stoga i spoznajno najvredniji. To se lako može utvrditi već i površnim pogledom u različite objavljene radove kao i izvještaje psihologa praktičara: psiholozi uvijek provjeravaju svoju metodologiju, uvijek nastoje dobiti što jasniji odnos među varijablama te su uvijek vrlo oprezni u svojim interpretacijama rezultata i zaključcima. Vrlo često se može naći pri kraju pisanih izvještaja o provedenim istraživanjima kako se autori kritički odnose prema svom radu i svojim rezultatima. Osobito je vidljiva stalna potreba za evaluacijom i reevaluacijom korištenih postupaka pri prikupljanju psihologijskih podataka

Takav pristup vidljiv je kod svih sljednika Zorana Bujasa, bilo da su bili bliži njegovi suradnici, primjerice u Odsjeku za psihologiju Filozofskog fakulteta u Zagrebu i u Laboratoriju za psihofiziologiju rada Instituta za medicinska istraživanja, bilo kao njegovi studenti koji su zatim djelovali u drugim institucijama ili fakultetima (npr. u Zadru i u Rijeci).

\section{Eksperimentalna psihologija}

Najjednostavnija definicija eksperimentalne psihologije mogla bi se ovako formulirati: psihologija koja kao glavni spoznajni alat koristi eksperiment. A eksperiment je istraživačka metoda kojom se manipulira nezavisnom varijablom da bi se utvrdio pretpostavljeni utjecaj na zavisnu varijablu, uz strogu kontrolu svih faktora, koji bi mimo nezavisne mogli djelovati na zavisnu varijablu. Eksperiment je jedini znanstveni postupak kojim se mogu otkrivati uzročno posljedične veze među pojavama. Zbog toga se primjena eksperimentalne metode veže uz laboratorije, jer je jedino u njima u najvećoj mjeri moguće kontrolirati tzv. relevantne faktore. ${ }^{25}$

25 Prema skraćenoj definiciji Zorana Bujasa, relevantni faktori su svi oni faktori koji bi mogli mimo nezavisne djelovati na zavisnu varijablu (bilješka s predavanja Zorana Bujasa). 
Međutim, u novije vrijeme radi se o proširenom pristupu u kojemu se istraživanja nastoje što bolje kontrolirati i izvan laboratorija, pa se tako taj pojam u stvari odnosi na svaku psihologiju koja se temelji na empirijskim podacima dobivenim znanstenim metodama. Zapravo, radi se načinu znanstveno-istraživačkog mišljenja koji je inaugurirala eksperimentalna psihologija (Petz, 2005). Pa tako postoji i pojam „eksperiment u prirodnim uvjetima“: izvedba planiranog eksperimenta u izvanlaboratorijskoj okolini, koja nije umjetno stvorena (Kljaić, 2005).

Psihofizička istraživanja Zorana Bujasa provedena su u laboratoriju. A samo su dva istraživanja, koje je Zoran Bujas izveo sa suradnicima koji bi se mogli okarakterizirati kvazi eksperimentalnim. To su: Bujas, Z., Kopajtić, N., Ostojčić, A., Petz, B. and Smolić, N. (1953). An experimental contribution to the psychology of competition in public schools. Acta Instituti Psychologici Universitratis zagrabiensis, 18, 1-14, te Bujas, Z. Petz, B. Krković, A. and Sorokin, B. (1961). Analysis of factors in intellectual performance under fatigue and without fatigue. Acta Instituti Psychologici Universitratis zagrabiensis, 23, 11-22.

Tipičan laboratorijski eksperiment provela je Mirjana Krizmanić (1972). Kako je dobro znano, miševi i štakori imali su u razvoju psihologije u zapadnom svijetu vrlo važnu - jedno vrijeme čak „stožernu“ - ulogu, napose u području istraživanja učenja. Tako i naša psihologija u svom razvoju nije zaostajala, i kod nas su postojala istraživanja s tim dragim životinjicama. U Institutu za medicinska istraživanja, u Laboratoriju za psihofiziologiju rada postojala je štakorska štala (i u tom su Laboratoriju obavljena brojna istraživanja sa štakorima), a jedna manja skupina štakora jedno je vrijeme postojala i u Odsjeku za psihologiju Filozofskog fakukteta u Zagrebu, u tzv. sjevernom podrumu. Profesori Filozofskog fakulteta $\mathrm{u}$ to vrijeme negodovali su jer im je smetalo što su u istoj zgradi s njima i štakori, iako, mora se priznati, ako se štala nije redovito i brižljivo čistila po Fakultetu se širio određeni vonj.

Budući da poznati rezultati istraživanja utjecaja ranog iskustva na brzinu učenja i sposobnost rješavanja problema nisu bili jednoznačni Mirjana Krizmanić je ispitivala kako rana stimulacija djeluje na brzinu učenja, kako djeluje okolina te perzistiraju li efekti ranog iskustva. Sudionici u istraživanju bili su joj štakori iz odsječke štakorske štale.

Ante Fulgosi (1932.-2005.) objavio je sedamdesetih i osamdesetih godina prošlog stoljeća, dvadesetak eksperimentalnih radova koji se dotiču psihofizike i osjetne psihologije. Točnije, koristio je teoriju informacija za objašnjenje nekih pojava u psihofizici, osjetnoj psihologiji i percepciji.

U radu iz 1972. navodi kako je u području psihologije teorija informacije bila orijentirana na određivanje tzv. kapaciteta kanala u različitim osjetnim i perceptivnim područjima. Više autora odredilo je taj kapacitet („Millerovih magičnih sedam") i tvrdilo da je broj bita u svakom kanalu nepromjenjiv (iako se dopušta određeni varijabilitet). Fulgosi vrlo opravdano prigovara tom tvrdom stavu i upo- 
zorava na činjenicu da se pri tom određivanju nije uzimao u obzir mogući utjecaj nesenzornih faktora, kao što su vježba, trening, pamćenje, način odlučivanja i dr. $\mathrm{Na}$ različitim matricama podražaja i odgovora on pokazuje kako su indeksi koji se uobičajeno koriste neosjetljivi na razlike, pa je razvio nov način izračunavanja količine prenesene informacije, primjerice Fulgosi, 1970; 1971; 1972; 1977.

U članku s naslovom „Informacijska psihofizika - nova objektivna psihofizika“ Fulgosi (1984), pomalo neuobičajeno za ozbiljan znanstveni diskurs, prikazuje teškoće klasične, objektivne, indirektne psihofizike inzistirajući na invalidnosti i Weberovog pa time i Fechnerovog zakona. Istina je da su mnogi eksperimenti pokazali da relativni diferencijalni limen nije konstantan duž cijele ljestvice supraliminalnih djelotovornih podražaja u nekom osjetnom području. Konstantan je u srednjem intenzitetnom području, dakle području podražaja s kojim se redovito u nornalnim prilikama srećemo, ali nije konstantan kod vrlo slabog i kod vrlo jakog podraživanja. No, Fulgosi posebno ističe, što je, inače, svakom istraživaču u području psihofizike poznato, kako je „diferencijalni limen kako se utvrđuje u klasičnoj psihofizici, neodjeljiv od procesa suđenja i odlučivanja, što znači da on ne odražava funkcionalne karakteristike samog osjetnog analizatora ili receptora, već cjelokupno psihičko stanje ili ugođenost ispitanika." Upravo će zbog toga, treba istaknuti kad se govori o istraživanjima u području psihofizike, svaki ozbiljan istraživač velik dio svojih napora posvetiti metodama prikupljanja psihofičkih podataka. Fulgosi, dalje, glorificira Stevensovu subjektivnu, direknu psihofiziku, za koju su doista brojna istraživanja pokazala da nije otporna na provjeru bilo koje od njegovih metoda subjektivnih procjena fizikalnih veličina. Već je Poulton (1968) utvrdio, a brojna istraživanja u Odsjeku za psihologiju potvdila (npr. Szabo, 1972), kako veličina Stevensovog eksponenta psihofizičke funkcije (je li manji od 1 , ili je 1 ili je veći od 1) ovisi o rasponu prezentiranih podražaja, o supraliminalnoj razini podražajnog niza, o veličini i poziciji standardnog podražaja itd. No, budući da su Stevensove metode subjektivne psihofizike vrlo jednostavne bile su i jesu istraživačima vrlo prihvatljive, komotne, pa su prihvaćene diljem različitih psihologijskih područja istraživanja.

Ipak, raspravu o klasičnoj (Fechnerovoj) i subjektivnoj (Stevensovoj) psihofizici Fulgosi zaključuje konstatacijom da se „Fechnerova psihofizika temelji na imaginarnoj i zamišljenoj jedva zamjetljivoj razlici za čije postojanje nema subjektivnih ni objektivnih dokaza“, a "Stevensova subjektivna psihofizika, iako realnija i objektivnija od Fechnerove, ne pruža nam pouzdane i stabilne informacije o funkcioniranju osjetnih sustava." Stoga, po njegovu mišljenju, psihofiziku treba postaviti na novu osnovicu, a tu osnovicu predstavljaju informacijski aspekti psihofizičkih sudova: „Donoseći sudove i procjene o razlikama u veličini svojih doživljaja ili o razlikama u veličini podražaja, ispitanik prenosi i određenu količinu informacije." (Fulgosi, 1984) 
Ali i ta nova „objektivna psihofizika“ temelji se na sudovima opažanika, kao što se temelji i Fecherova i Stevensova psihofizika, jedino što se rezultati prikazuju na različite načine.

U novije vrijeme sve se više propitkuje upotreba teorije informacije u psihologiji. Tako R. D. Luce, (2003) u sažetku članka „Whatever happened to information theory in psychology?" piše ovako: „Iako je Shannonova teorija informacije živa i prikladna u brojnim područjima, nakon početne pomodnosti u psihologiji tijekom 1950-ih i 1960-ih, nije više toliki čimbenik u psihologijskoj teoriji, izuzevši riječ bit." Navodi mišljenje Laminga (2001, prema Luce, 2003) koji naglašava da Shannonova definicija pojma teorije informacije zahtijeva da se ne prenose pojedinačni signali nego dugački nizovi kako bi se uklonila redundancija. Luce (2003), pak, misli da je glavni razlog inkompatibilnosti teorije informacije u psihologiji činjenica da su podražaji u psihologijskim eksperimentima strukturirani, a teorija informacija nije namijenjena takvoj vrsti informacija.

Kolega Dražen Domijan (profesor u Odsjeku za psihologiju Filozofskog fakulteta u Rijeci) upozorio me, usmenom komunikacijom, na neke suvremene pokušaje određivanja psihofizičkog odnosa. Tako je Kenneth Norwich (Norwich, K. H. (1993). Information, Sensation, and Perception. San Diego: Academic Press) zamislio, pomoću teorije informacije, novi psihofizički zakon zasnovan na entropiji. Taj zakon u sebi sadržava i Fechnerov i Stevensov psihofizički zakon, kao specijalne slučajeve. No, to je sasvim teorijska zamisao koja nije ostavila znatnijeg traga. Ipak, K. H. Norwich, u članku iz 2005. (Physical entropy and the senses. Acta Biotheoretica, 53, 167-180) piše da je na dva specifična osjetna modaliteta - okus slanog i glasnoća stalnog tona - pokazano da su zakoni osjećanja (Fechnerov logaritamski i Stevensov potencijalni) izraz entropije po molu ${ }^{26}$ podražaja, tj. zakon osjećanja linearna je funkcija molarne entropije. Prema mišljenju tog autora, značenje njegovih opažanja leži u povezanosti fenomena „osjećanja“ (osjetnih doživljaja) izravno s fizikalnom mjerom. Ako su fizikalni zakoni univerzalni onda su i zakoni osjećanja i percepcije također univerzalni.

Osim u Odsjeku za psihologiju Filozofskog fakulteta u Zagrebu velik broj laboratorijskih eksperimenta proveden je u Laboratoriju za psihofiziologiju pri Institutu za medicinska istraživanja u Zagrebu. Mnogi su bili pod vodstvom Zorana Bujasa, ali su, primjerice, Branko Sremec te Anđelko Krković, također, napravili veći broj eksperimenta samostalno, a najviše Stjepan Vidaček, kao jedini autor ili sa svojim suradnicima, koji je nakon Zorana Bujasa bio voditelj tog Laboratorija (vidi: Vidaček, 1957; 1965; Vidaček \& Wishner, 1971; 1972; Bujas, Sremec, Vidaček, 1965).

Suradnik Zorana Bujasa u Laboratoriju za psihofiziologiju rada Branko Sremec (1931.-2011.) prešao je 1978. godine u Odsjek za psihologiju Filozofskog

$\overline{26}$ Mol - jedinica količine tvari. 
fakulteta u Rijeci i tamo se, osim nastave, bavio eksperimentalnim istraživanjima percepcije (vidi: Sremec i Smojver-Ažić, 1992; Sremec, 1993).

Boris Petz (1919.-2005.) surađivao je u Laboratoriju za psihofiziologiju rada Instituta za medicinska istraživanja sa Zoranom Bujasom od 1948. godine, a od 1960. bio je profesor u Odsjeku za psihologiju Filozofskog fakulteta u Zagrebu. U Laboratoriju za psihofiziologiju rada napravio je veći broj laboratorijskih istraživanja, u suradnji sa Zoranom Bujasom i samostalno. U članku „Prof. dr. Boris Petz - život i rad“, objavljenom u broju Primijenjene psihologije posvećenu Borisu Petzu, Željko Jerneić i Branko Šverko (1989) prikazuju istraživački rad Borisa Petza: radove usmjerene na evaluaciju i iznalaženje postupaka za ranu detekciju umora, potom elektrofiziološka istraživanja za vrijeme rada te istraživanja mehanizama umora i djelotvornosti odmaranja. Neka od Petzovih istraživanja su: Petz, 1954; 1957; 1970; Bujas and Petz, 1954; 1964. U spomenutom broju Primijenje psihologije objavljena je i bibliografija Borisa Petza.

Student Zorana Bujasa, Ilija Manenica, suosnivač Odsjeka za psihologiju u Zadru, napravio je veći broj laboratorijskih istraživanja u području psihofiziologije radne aktivnosti (vidi: Manenica, 1987a; 1987b).

Znanstvena psihologija rodila se kao eksperimentalna psihologija. U njezinim počecima, od Webera, Fechnera i Wundta dalje, psihologijski su se eksperimenti provodili u području osjetne psihologije, percepcije i psihofiziologije. Kasnije, za vladavine biheviorizma, korištenje eksperimenta intenzivno se proširilo na područje učenja.

Klasični eksperiment zahtijeva pojednostavljivanje stvarnosti: izoliranje jedne nezavisne varijable kako bi se promatralo postoji li utjecaj na izoliranu zavisnu varijablu. Za mjerenje eventualnih promjena u zavisnoj varijabli razvijeni su doista brojni postupci, a njih psiholozi uvijek brižljivo provjeravaju ne bi li utvrdili imaju li prihvatljiva metrijska svojstva. Isto tako uočeni su mnogobrojni tzv. relevantni faktori koji mimo nezavisne mogu djelovati na zavisnu varijablu, pa poseban napor istraživači posvećuju postupcima njihove kontrole.

Ali, postojali su i opravdani prigovori eksperimentu u psihologiji, a glavni je izvor prigovorima pitanje spoznajnih dometa eksperimentalno dobivenih rezultata: često nedostatna vanjska i ekološka valjanost. Želja za što boljom ekološkom valjanošću pokazuje nastojanja psihologa da psihologija bude praktičnija (Parducci and Sarris, 1984). Stoga je eksperiment doživio promjene i poboljšanja, upravo u smislu boljeg transfera rezultata eksperimenta na životne prilike, dakle, u smislu bolje generalizacije rezultata. Već od sredine prošlog (20.) stoljeća psihologijski eksperiment dobivao je ponešto proširen smisao. Eksperiment $s$ jednim slučajem postao je opće prihvaćen, a šezdesetih godina 20. stoljeća pojavila se eksperimentalna psihologija mnogostrukih varijabli (engl. multivarijable experimental psychology ${ }^{27}$ )

27 Raymond Catell osnovao je 1960. godine Society of Multivariate Experimental Psychology koje se na prvom mjestu bavi multivarijatnim statističkim modelima. 
(Ardila, 1984). Legalitet su dobili i „eksperimenti s malo N“.Osim toga, sve više se koristi brižljivo proveden eksperiment za korelacijsku analizu rezultata. Kod nas, primjerice, u uzorno pripremljenom i provedenom laboratorijskom eksperimentu Branimir Šverko (1973) ispitivao je „postoji li povezanost između osobina ličnosti motrilaca i njihove uspješnosti pri detekciji rijetkih signala, te - ako postoji - kakva je njena priroda i koliki je stupanj te povezanosti“". Sličan laboratorijski eksperiment proveo je i Željko Jerneić (1988) za svoju magistarsku radnju. Ispitivao je nalazi li se u osnovi uspješnosti u različitim zadacima posebna sposobnost za simultano djelovanje. Glavna obrada rezultata bila je pomoću faktorske analize koja je trebala pokazati može li se iz korelacijske matrice učinaka izlučiti jedan faktor. Tako su vrlo uspješno združeni klasični psiholigijski eksperiment i pristup koji se naziva diferencijalna psihologija.

U mnogim područjima psihologije - socijalnoj psihologiji, kliničkoj psihologiji, razvojnoj psihologiji itd. - koriste se tzv. kvazi-eksperimentalna istraživanja. U načelu, razlika između eksperimentalnih i kvazi-eksperimentalnih istraživanja samo je u manipuliranju varijablama (Ardila, 1984), te u načinu selekcioniranja sudionika u istraživanju. Ali i u drugim istraživačkim pristupima, kao što su korelacijska istraživanja, istraživanja u tzv. prirodnim uvjetima, neeksperimentalna kvantitativna istraživanja (Stadish, Cook and Campbell, 2002), dobivaju se rezultati koji imaju ili mogu imati spoznajnu vrijednost. Jer, a to je važna činjenica, psihologijska istraživanja po svojoj strukturi i znanstvenoj rigoroznosti uvijek pokušavaju što više zadržati temeljne karakteristike eksperimenta. Ponovo ističem: eksperimentalna psihologija uvela je u psihologiju način mišljenja, način kojim se dolazi do što valjanijih podataka, čega se, općenito govoreći, pridržavaju hrvatski psiholozi-istraživači - a taj duh istraživačke rigoroznosti usadili su hrvatskim psiholozima Ramiro i Zoran Bujas.

Već i letimičnim pogledom na članke u najnovijim brojevima prestižnih psihologijskih časopisa koji u svom naslovu nose termin „eksperimentalni“, poput Journal of Experimental psychology: General; Journal of Experimental Psychology: Human Perception and Performance; Journal of Experimental Psychology: Learning, Memory and Cognition; Quarterly Journal of Experimental Psychology može se vidjeti $\mathrm{da}$, osim klasičnih eksperimentalnih radova, ti časopisi objavljuju i druge vrste empirijskih istraživanja koja mogu povezivati klasični eksperiment i diferencijalnu psihologiju, kao i suvremene modifikacija empirijskog i eksperimentalnog pristupa u znanstvenoj psihologiji. ${ }^{28}$

28 Uvid u te najnovije brojeve navedenih časopisa omogućila mi je kolegica Marijana Glavica, kojoj ponovno izražavam zahvalnost. 


\section{Literatura}

Ajduković, D. (1980). Površina elektrode i električni okus. Neobjavjen magistarski rad. Zagreb: Odsjek za psihologiju Filozofskog fakulteta.

Ajduković, D. (1982). Utjecaj nekih karakteristika električnog podraživanja jezika na supraliminalne senzorne efekte. Neobjavljen doktorski rad. Zagreb: Odsjek za psihologiju Filozofskog fakulteta.

Ardila, R. (1984). Contemporary aspects of psychological experimentation. In: V. Sarris \& A. Parducci (Eds.), Perspectives in Psychological experimentation: Toward the Year 2000. Hillsdale, NJ: Lawrence Erlbaum Associates, Publishers.

Arnold, Đ. (1923). Psihologija za srednja učilišta. Zagreb: Narodna knjižnica.

Bartolović, B. (177). Brzina porasta intenziteta podražaja u vremenu i neki aspekti funkcionalne sposobnosti okusnog analizatora. Neobjavljen magistarski rad. Zagreb: Filozofski fakultet.

Bartolović, B. (1986). Metrijske karakteristike skale školskih ocjena u funkciji različitih načina ocjenjivanja. Primijenjena psihologija, 7, 15-20.

Bartolović, B. (1991). Zoran Bujas' research and proposals in the area of dokimology /assessment of scolastic achievement/. Revija za psihologiju, 21(1), 29-31.

Basariček, S. (1878). Kratko izkustveno dušoslovje. Zagreb: Hrvatski pedagogijsko-književni zbor.

Benjamin, L.T., Jr. (2007). A Brief History of Modern Psychology. Malden, MA: Blackwell Publishing.

Boring, E.G. (1950). A History of Experimental Psychology. New York: Appleton-CenturyCrofts.

Brenk, K. (1977). Komparativna veljavnost glavnih psihofizičnih metod. Neobjavljen doktorski rad. Ljubljana: Oddelek za psihologijo Filozofske fakultete v Ljubljani.

Bujas, R. (1921). Istraživanja o fizičnim uvjetima psihogalvanskog fenomena. Liječnički vjesnik, 43(3), 113-119.

Bujas, R. (1922). Die physischen Bedingungen des psychogalvanischen Phänomens. U: Materijali VII. Kongresa eksperimentalne psihologije. Marburg.

Bujas, R. (1937). Zur Klärung einer Tatsachenfrage im Geiete des psychogalvanischen Phänomenons. American Journal of Psychology, 50, 362-368.

Bujas, R. (1937). O Ocjenjivanju. Napredak, br. 9-10.

Bujas, R. (1943). Pitanje duhoznanstvene psihologije. Napredak, LXXXIV, br. 9-10.

Bujas, R. i Bujas, Z. (1937a). Tahistoskopsko ispitivanje ćirilskih i latinskih slova. Nastavni vjesnik, 45 (1/3), 28-44.

Bujas, R. und Bujas, Z. (1937b). Ein Test zur Untersuchung der Lesbarkeit von Druckschriften. Acta Instituti Psychologici Universitatis zagrabiensis, 2(2), 3-9.

Bujas, R. i Bujas, Z. (1937c). Zamjetljivost latinskih i ćirilskih slova u indirektnom gledanju. Napredak, 78(3/4), 11-119.

Bujas, R. i Bujas, Z. (1938). Čitljivost latinice i ćirilice na osnovi najmanjeg osvjetljenja. Napredak, 79(3), 122-129.

Bujas, R. i Bujas, Z. (1942). Dobivanje psihologijskih podataka i njihovo računsko obradivanje. Zagreb: Hrvatska državna tiskara.

Bujas, R., Bujas, Z. i Blašković, J. (1941). Subjektivni faktor u školskom ocjenjivanju, Napredak, br. 3, 97-125.

Bujas, Z. (1935). Prilog tumačenju nekih pojava u području okusa. Apotekarski Vjesnik, 15, 77-81, 141-144, 184-188, 225-226. 
Bujas, Z. (1937). O zakonima zbrajanja i odbijanja okusa. Apotekarski Vjesnik, 17, 39-40, 84-88.

Bujas, Z. (1941). Točnost i osjetljivost nastavnika pri ocjenjivanju školskih zadaća. Napredak, br. 4-6, 152-165.

Bujas, Z. (1945). Elementi psihologije. Zagreb: Hrvatski pedagoško-književni zbor.

Bujas, Z. (1966). Provjeravanje znanja - ispitivač ili test? Liječnički vjesnik, br. 7.

Bujas, Z. (1971). Electrical Taste. In: L. Beidler (Ed.), Handbook of Sensory Physiology, IV (2), (180-199). Heidelberg.

Bujas, Z. (1972). Psihofizika nekad i danas. Psihološke raszprave. Ljubljana: Društvo psihologa Slovenije.

Bujas, Z. (1973). Ramiro Bujas začetnik nastave i znanstvenog rada na području psihologije u Hrvatskoj. U: D. Stary (ur.), Stručni skupovi psihologa „Dani Ramira Bujasa“ 1970. i 1972. (str. 9-13). Zagreb: Društvo psihologa SR Hrvatske.

Bujas, Z. (1973). Pojave osjetne adaptacije. U: D. Stary (ur.), Stručni skupovi psihologa „Dani Ramira Bujasa" 1970. i 1972.(str. 17-26). Zagreb: Društvo psihologa SR Hrvatske.

Bujas, Z. (1975). Kriteriji efikasnosti signala u psihofizici. U: D. Stary (ur.), Stručni skup psihologa „Dani Ramira Bujasa“ 1974. Zagreb: Društvo psihologa SR Hrvatske. (str. 3139). Zagreb: Društvo psihologa SR Hrvatske.

Bujas, Z. (1981). Uvodu u metode eksperimentalne psihologije. Zagreb: Školska knjiga.

Bujas, Z., Ajduković, D., \& Mayer, D. (1984). Psychophisical investigation of taste effects provoked by simultaneous application of taste solutions and electrical current. Acta Biologica JAZU, 10(1), 1-21.

Bujas, Z., Ajduković, D., \& Mayer, D. (1987). Taste effectiveness of some sodium and chloride salts. Acta Instituti Psychologici Universitatis zagrabiensis, 17, 3-9.

Bujas, Z., Ajduković. D., Szabo, S., Mayer, D., \& Matutinović, Ž. (1999). Perception of the form of stimulus increment as a method in assesment of the psychophysical relationship. Perceptual and Motor Skills, 89, 509-531.

Bujas, Z., Ajduković. D., Szabo, S., Mayer, D., \& Vodanović, M. (1994). Adaptation to $\mathrm{NaCl}$ evaluated by reaction time and magnitude estimation. Acta Biologica HAZU, 17, 1-9.

Bujas, Z., Ajduković, D., Szabo, S., Mayer, D., \& Vodanović, M. (1986). Some observation on the mechanics of electrical taste. Acta Bilogica JAZU, 12(1), 1-13.

Bujas, Z., Ajduković, D., Szabo, S., Mayer, D., \& Vodanović, M. (1995). Central processes in gustatory adaptation. Physiology \& Behavior, 57, 875-880.

Bujas, Z., Ajduković, D., \& Vodanović, M. (1985). Successive taste contrast and water taste in man. Acta Biologica JAZU, 11(1), 1-20.

Bujas, Z., Ajduković, D., Vodanović, M., \& Mayer, D. (1987). The influence of electric current on the saltiness of some sodium and chloride salts. Acta Instituti Psychologici Universitatis zagrabiensis, 29, 81-87.

Bujas, Z. et Petz, B. (1954). Les modifications des ondes alpha au cours du travail mental prolongè. Le Travail Humain, 17, 201-206.

Buajs, Z., \& Petz, B. (1964). Amplitude of the arm aftermovement as the possible indicator of effort. Acta Instituti Psychologici zagrabiensis, 33-48. 65-72.

Bujas, Z., Kovačić, M., \& Rohaček, A. (1975). Psychophysical function based on sonfidence rating. Acta Instituti Psychologici Universitatis zagrabiensis, 74, 3-16.

Bujas, Z. Krizmanić, M., \& Krković, A. (1975). Confidence rating as a complement of the cognitive test score. Acta Instituti Psychologici Universitatis zagrabiensis, 77, 31-37. 
Bujas, Z., Rohaček, A., \& Kovačić, M. (1975). Electrode area and electrical taste thresholds. Acta Instituti Psychologici Universitatis zagrabiensis, 76, 25-29.

Bujas, Z., Rohaček, A., \& Szabo, S. (1977).L'utilisation de la certitude subjective dans les mesures psychophysiques. Acta Instituti Psychologici Universitatis zagrabiensis, 79, 3-15.

Bujas, Z., Dogan, S., Mayer, D., \& Ajduković, D. (1980). Relation between stimulus range, direct lodness estimation and average cortical V-potential. Acta Instituti Psychologici Universitatis zagrabiensis, 89, 23-28.

Bujas, Z., Sremec, B. i Vidaček, S. (1965). Doživljaj umora i njegove asocijacije s nekim drugim varijablama. Arhiv higijene rada, 16, 11-123.

Car-Gavrilović, I. (1965). Kriterij ocjenjivanja i intelektualni nivo razreda. Pedagoški rad, 3-4, 162-167.

Colman, A.M. (2006). Oxford Doctionary of Psychology. Oxford: Oxford University Press.

Đorđevski, R. (1964). Objektivnost komisijskog ocjenjivanja. Pedagoški rad, 1-2, 20-30.

Filipović, V. (1938). Moderna psihologija u pedagogiji. Zagreb: Minerva.

Filipović, V. (ur.) (1965). Filozofijski rječnik. Zagreb: Matica Hrvatska.

Fulgosi, A. (1970). Informacijska vrijednost zvučnih ritmova. Revija za psihologiju, 1, 11-13.

Fulgosi, A. (1971). O jednom nedostatku sadašnjih načina izračunavanja količine prenesene informacije. Ravija za psihologiju, 2, 7-9.

Fulgosi, A. (1972). Pristranost izračunate količine prenesene informacije i broj prezentiranja svakog podražaja. U: IV. kongres psihologa SFRJ: Psihološke raszprave (str. 122-125). Ljubljana: Društvo psihologa Slovenije i Filozofska fakulteta u Ljubljani.

Fulgosi, A. (1977). Teorija informacije u psihofizici. U: D. Stary (ur.), Stručni skup „Dani Ramira Bujasa“ 1976. (str. 87-96). Zagreb: Društvo psihologa SR Hrvatske.

Fulgosi, A. (1984). Informacijska psihofizika - nova objektivna psihofizika. U: Dani psihologije '83: zbornik radova (str. 11-28). Zadar: Filozofski fakultet, Odsjek za psihologiju.

Gregorač, J. (1991). Zoran Bujas' role in the activities and development of the Department of Psychology in Ljubljana. Revija za psihologiju, 21(1), 11-12.

Grgin, T. (1980). Pregled dokimoloških istraživanja započetih radovima Ramira Bujasa. U: Stary, D. (ur.), Stručni skup psihologa „Dani Ramira Bujasa“ 1979 (str. 29-40). Zagreb: Društvo psihologa SR Hrvatske.

Grgin, T. (1986). Školska dokimologija: procjenjivanje i mjerenje znanja. Zagreb: Školska knjiga.

Grgin, T. (1994). Školska dokimologija: uvod u prirodoznanstvenu psihologiju. Jastrebarsko: Naklada Slap.

Grgin, T. (1997). Edukacijska psihologija. Jastrebarsko: Naklada Slap.

Grgin, T. (2001). Školsko ocjenjivanje znanja. Jastrebarsko: Naklada Slap.

Grlić, D. (1982). Leksikon filozofa. Zagreb: Naprijed.

Heereman, J., Walter, H., \& Heekeren, H.R. (2015). A task-independent neural repesentation of subjective certainty invisual perception. Frontiers in Human Neuroscience, 9, 551.

Hergenhahn, B.R. (2001). An Introduction to the History of Psychology. Belmont, CA: Wadsworth/Thomson Learning

Hrvatska opća enciklopedija (1999). Zagreb: Leksikografski zavod Miroslav Krleža.

Huber, H.P., \& Seybold. I. (1999). Ramiro Bujas i psihologija u Grazu oko 1900. godine. U: Psihologija: znanost za čovjeka 21. stoljeća (str. 9-14). Zagreb: Odsjek za psihologiju Filozofskog fakulteta u Zagrebu. 
Ivanec, D. (1996). Stimuli context effect on simple reaction time: The importance of preparatory interval. Proceedings of the Twelfth Annual Meeting of the International Society for Psychophysics (str. 293-298). Padova: University of Padova.

Jerneić, Ž. (1988). Ispitivanje individualnih razlika prilikom „simultanog“ obavljanja aktivnosti. Neobjavljeni magistarski rad. Zagreb: Odsjek za psihologiju Filozofskog fakulteta.

Jerneić, Ž. i Šverko, B. (1989). Prof. dr. Boris Petz - život i rad. Primijenjena psihologija, 10, $3-12$.

Kale, E. (1981). Povijest civilizacije. Zagreb: Školska knjiga.

Kljaić, S. (2005). Eksperiment u prirodnim uvjetima. U: Petz, B., Psihologijski rječnik. Jastrebarsko: Naklada Slap.

Kolesarić, V. (1979). Adaptacija i rekuperacija kod električki izazvanih fosfena. Neobjavljen doktorski rad. Zagreb: Odsjek za psihologiju Filozofskog fakulteta u Zagrebu.

Kolesarić, V. (1981). Vidni osjeti izazvani električnim podraživanjem oka. Zagreb: Društvo psihologa Hrvatske.

Kolesarić, V. (1983). Stupanj deklarirane sigurnosti subjekta kao dodatni kriterij perceptivne efikasnosti podražaja. U: Z. Bujas, (ur.), Psihologija osjeta i psihofizika (str. 35-43). Zagreb: Društvo psihologa Hrvatske.

Kolesarić, V. (1987). The subject declared degree of confidence as an additional criterion of perceptive stimulus effects. Acta Instituti Psychologici Universitatis zagrabiensis, 17, 49-57.

Kolesarić, V., Krizmanić, M. i Špehar, B. (1986). Uputom inducirane individualne razlike u "senzornom" i "motornom" stavu pri ispitivanju vremena jednostavne senzomotorne reakcije. Primijenjena psihologija, 7(1-4), 275-280.

Kolesarić, V. i Pavlina, Ž. (1990). Razvoj psihologije na Zagrebačkom sveučilištu. U: Sveučilište $u$ razvoju znanosti od 1669. do danas. Zagreb: Sveučilište u Zagrebu.

Kolesarić, V. i Pavlina, Ž. (2005). Životopis akademika Zorana Bujasa. U: B. Sokač (ur.), Zoran Bujas. 1910.-2004., (str. 13-17). Zagreb: Hrvatska akademija znanosti i umjetnosti.

Kolesarić, V., Komar, Z. i Rohaček, A. (1984). Podražajni kontekst i vrijeme jednostavne senzomotorne reakcije. U: K. Lacković-Grgin (ur.), IV. Dani psihologije u Zadru (str. 105-110). Zadar: Filozofski fakultet u Zadru.

Kolesarić, V., Rohaček, A. i Komar, Z. (1984). Ispitivanje utjecaja podražajnog konteksta na vrijeme jednostavne reakcije za grupirane podražaje. U: D. Stary (ur.), VI. "Dani Ramira Bujasa" (str. 69-72). Zagreb: Društvo psihologa Hrvatske.

Koriat, A. (2011). Subjective confidence in perceptual judgments: A test of the self- consistency model. Journal of Experimental Psychology: General, 140(1), 117-139.

Krantz, J.H. (2008). Psychophysics. In: Davis, S.F. \& Buskist, W. (Eds.), 21st Century Psychology. A Reference Handbook (177-186). Los Angeles: Sage.

Krizmanić, M. (1972). Utjecaj ranog iskustva na kasnije ponašanje štakora. U: Psihološke razsprave. Ljubljana: Društvo psihologa Slovenije i Filozofski fakultet u Ljubljani.

Krstić, K. (1961). Professor Ramiro Bujas. Acta Instituti Psychologici Universitatis zagrabiensis, 22, 3-9.

Kučera, E. (1914). Psihogalvanska refleksna pojava prema svome značenju za psihologiju čuvstava. Nastavni vjesnik, 23.

Kučera, E. (1923). Osnutak Psihologijskog instituta u Višoj pedagoškoj školi. Kršćanska škola, XXVI(5/6).

Kučera, E. (1924). Ispitivanje inteligencije u svojoj pedagoškoj primjeni. Zbornik za pučku prosvjetu. 
Kučera, E. (1930). Experimentalle Beiträge zur Charakteristik der von Willenshandlung. Archiv für die gesamte Psychologie, 77(1/2).

Kučera, E. (1933). Experimentalle Beiträge zur Charakteristik von Willensstufen. Acta Instituti Psychologici Universitatis zagrabiensis, 1(3).

Kučera, E. (1947). Eksperimentalni prilozi karakteristici motivacije u voljnom djelovanju. Rad Jugoslavenske akademije znanosti i umjetnosti. Odjel za prirodne i medicinske nauke, 273, 129-160.

Kulenović, A., \& Krzmanić, M. (1991). Zoran Bujas' work on the construction of psychological measurement instruments. Revija za psihologiju, 21(1), 25-28.

Laming, D. (2001). Statistical information, uncertainity, and Bayes' theorem: Some application in experimental psychology. In: S. Benferhat \& P. Besnard (Eds.), Symbolic and quantitative approaches to reasoning with uncertainty (str. 635-646). Berlin: Springer-Verlag

Loveless, E., \& Thetford, P. (1966). Interpretation and conditioning of the positive andnegative components of the skin potential response. Psychological Record, 16, 357.

Luce, R.D. (2003). Whatever happened to information theory in psychology? Review of General Psychology, 7(2), 183-188.

MacKay, D.M. (1963). Psychophysics of perceived intensity: A theoretical basis for Fechner's and Stevens' laws. Science, 139, 1213-1216.

Manenica, I. (1987a). An evaluation of a new method for mental load assessment. In: J.R. Wilson, E.N. Corlett \& I. Manenica (Eds.), New Methods in Applied Ergonomics (str. 223231). London: Taylor and Francis Ltd.

Manenica, I. (1987b). Odnos samoprocjene stanja aktivacije i razine nekih fizioloških varijabli. Radovi, 26(3), 131-138.

Marotti, B. (2016). Povijest filozofije i povijest znanosti u istraživanjima akademika Žarka Dadića. Historijski zbornik, LXIX, 485-490.

Marx, M.H. (1987). Systems and Theories in Psychology. New York: McGraw-Hill Book Company.

Mayer, D. (1974). Izrada jednostavnih aparata i pribora - tradicija zagrebačkog Odsjeka za psihologiju. U: Dani Ramira Bujasa. Zagreb: Društvo psihologa Hrvatske (str. 19-29).

Ognjenović, P. (1991). Zoran Bujas and the great issues of psychophysics. Revija za psihologiju, 21(1), 19-20.

Parducci, A., \& Sarris, V. (1984). The experimental approach: Dead end or via regia of psychology? In: V. Sarris \& A. Parducci (Eds.), Perspectives in Psychological experimentation: Toward the Year 2000. Hillsdale, NJ: Lawrence Erlbaum Associates, Publishers.

Pavlina, Ž. i Kovačić, M. (1973). Imenik psihologa članova Društva psihologa u Hrvatskoj. Zagreb: Društvo psihologa SR Hrvatske.

Pavlina, Ž. i Kolesarić, V. (1984). Nakladna djelatnost Psihologijskog instituta (1924.-1984.). Zagreb: Društvo psihologa Hrvatske.

Pavlina, Ž. i Kolesarić, V. (1987). Značenje Psihologijskog instituta Zagrebačkog sveučilišta za razvoj psihologije u nas. Primijenjena psihologija, 8, 25-35.

Pavlina, Ž. i Kolesarić, V. (1991). Zoran Bujas: Biography. Revija za psihologiju, 21(1), 3-4.

Pavlina, Ž. i Kolesarić, V. (2005). O znanstvenom i stručnom radu akademika Zorana Bujasa. U: B. Sokač (ur.), Zoran Bujas. 1910.-2004. Zagreb: Hrvatska akademija znanosti i umjetnosti.

Pavlina, Ž., Kolesarić, V., Matešić, K. i Topić, F. (2007). Psychology in Croatia. Zagreb: Croatian Psychological Association. 
Petz, B. (1954). Ekonomičnost rada pod utjecajem psiholoških stimulatora. Arhiv za higijenu rada i toksikologiju, 5, 321-329.

Petz, B. (1957). Pokusi s Dotting testom u stanju svježine i u stanju umora. Arhiv za higijenu rada $i$ toksikologiju 8, 223-227.

Petz, B. (1970). Eksperimentalno ispitivanje „slike proizvoda“. Revija za psihologiju, 1, 87-96.

Petz, B. (1979). Ramiro Bujas, osnivač znanstvene psihologije u Hrvatskoj. Psihologijski vjesnik, 4, 2-4.

Petz, B. (1983). Kratak prikaz dosadašnjeg rada akademika Zorana Bujasa. Primijenjena psihologija, 4, 1-8.

Petz, B. (ur.) (2005). Psihologijski rječnik. Jastrebarsko: Naklada Slap.

Petz, B., \& Vidaček, S. (1991). Zoran Bujas' research in the field of psychophysiology of work. Revija za psihologiju, 21(1), 21-23.

Poulton, E.C. (1968). The new psychophysics: Six models for magnitude estimation. Psychological Bulletin, 69, 1-19.

Roeckelein, J.E. (2006). Elsevier's Dictionary of Psychological Theories. Amsterdam: Elsevier.

Rohaček, A. (1973). Tahistoskopsko ispitivanje čitljivosti riječi pisanih ćirilicom i latinicom. U: D. Stary (ur.), Stručni skupovi psihologa „Dani Ramira Bujasa“ 1970. i 1972. (str. 203208). Zagreb: Društvo psihologa SR Hrvatske.

Rohaček, A. (1976). Čitljivost slova ćirilice i latinice u sklopu riječi i čestina njihova pojavljivanja. U: R. Đorđevski (ur.), V. Kongres psihologa Jugoslavije: materijali 1 (str. 145-148). Skopje: Društvo psihologa SR Makedonije.

Rohaček, A. (1978). Ispitivanje čitljivosti latinice $i$ ćirilice i provjeravanje djelovanja gornjih donjih nastavaka slova na čitlivost riječi pisanih ćirilicom i latinicom. Neobjavljen magistarski rad. Zagreb: Odsjek za psihologiju Filozofskog fakulteta.

Shadish, W.R., Cook, T.D., \& Campbell, D.T. (2002). Experimental and Quasi-experimental Designs for Generalized Causal Inference. Boston: Houghton Mifflin Company.

Sokač, B. (ur.) (2005). Zoran Bujas, 1920.-2004. Zagreb: Hrvatska akademija znanosti i umjetnosti.

Sremec, B. (1980). Psihogalvanski fenomen u istraživanjima Ramira Bujasa. U: Stary, D. (ur.), Stručni skup psihologa „Dani Ramira Bujasa“ 1979. Zagreb: Društvo psihologa SR Hrvatske.

Sremec, B. (1993). Percepcija oblika. Godišnjak Zavoda za psihologiju, 2. Rijeka: Odsjek za psihologiju Filozofskog fakulteta u Rijeci.

Sremec, B. i Smojver,-Ažić, S. (1992). Percepcija zakrivljenih crta. Godišnjak Zavoda za psihologiju, 1. Rijeka: Odsjek za psihologiju Filozofskog fakulteta u Rijeci.

Staddon, J.E.R. (1978). Theory of behavioral power functions. Psychological Review, 85, 305-320.

Stipetić-Szabo, S. (1967). Effest of number of stimuli on the estimation of stimulus intensity. Acta Instituti Psychologici Universitatis zagrabiensis, 58, 81-84.

Szabo-Stipetić, S. (1971). Neki metodološki problemi Stevensove psihofizike. Neobjavljen magistarski rad. Zagreb: Filozofski fakultet.

Szabo, S. (1972). Utjecaj čestine zadavanja standarda na procjenu veličina. U: IV. kongres psihologa SFRJ: Psihološke raszprave (str. 137-140). Ljubljana: Društvo psihologa Slovenije i Filozofska fakulteta v Ljubljani.

Szabo, S. (1973). Stupanj deklarirane sigurnosti kao dodatna informacija u psihofizičkim mjerenjima. U: D. Stary (ur.), Stručni skupovi psihologa „Dani Ramira Bujasa“, 1970. i 1972. (str. 209-214). Zagreb: Društvo psihologa SR Hrvatske. 
Szabo, S. (1976). Utjecaj postepenog porasta i trajanja podražaja na apsolutnu osjetljivost u području električnog okusa. Neobjavljen magistarski rad. Zagreb: Odsjek za psihologiju Filozofskog fakulteta.

Szabo, S. (1977). Psychopysical strength-duration relatinship in the field of electrical taste. Acta Instituti Psychologici Universitatis zagrabiensis, 85, 65-70.

Szabo, S., Bujas, Z., Ajduković, D., Mayer, D., \& Vodanović, M. (1997). Influence of the intensity of $\mathrm{NaCl}$ solutions on adaptation and recovery time course. Perception \& Psychophysics, 59, 180-186.

Szabo, S., Kolesarić, V., \& Brenk, K. (1991). Research of Zoran Bujas in the field of psychophysics and sensory psychophysiology. Revija za psihologiju, 21(1), 13-17.

Šestak, I. (2010). Hrvatski neoskolastički priručnici filozofije o čovjeku. Prilozi, 71-72, 91-125.

Šverko, B. (1973). Pozornost pri detektiranju rijetkih signala u odnosu na neke osobine ličnosti motrilaca. Neobjavljen doktorski rad. Zagreb: Odsjek za psihologiju Filozofskog fakulteta.

Tarbuk, D., \& Koren, I. (1991). Zoran Bujas' work in the field of vocational guidance. Revija za psibologiju, 21(1), 33-35.

VandenBos, G.R. (Ed.) (2007). APA Dictionary of Psychology. Washington, DC: American Psychological Association.

Vidaček, S. (1957). Utjecaj umora na reprodukciju pokreta ruke i stabilnost pritiska šake. Arhiv za higijenu rada $i$ toksikologiju, 8, 229-234.

Vidaček, S. (1965). Djelovanje simpatikomimetika na radni učinak kod tjelesnih radova. Arhiv za higijenu rada i toksikologiju, 16, 136-160.

Vidaček, S., \& Wishner, J. (1971). Influence of expectation of task duration on efficiency of muscular activity. Journal of Applied Psychology, 55, 564-569.

Vidaček, S., \& Wishner, J. (1972). Difficulty and the efficiency of muscular activity. Journal of Applied Psychology, 56, 510-512.

Zenko, F. (ur.(1995). Novija hrvatska filozofija. Zagreb: Školska knjiga.

Zimmermann, S. (1923). Temelji psihologije. Opća nauka o svijesnom životu ljudske duše. Zagreb: Hrvatska bogoslovna akademija. 